\title{
27. A PRELIMINARY STUDY OF THE EVOLUTION OF CHIASMOLITHUS IN THE MIDDLE EOCENE TO OLIGOCENE OF SITES 647 AND $748^{1}$
}

\author{
John V. Firth ${ }^{2}$ and Sherwood W. Wise, Jr. ${ }^{3}$
}

\begin{abstract}
In this preliminary biometric study of the calcareous nannofossil species Chiasmolithus expansus, Chiasmolithus oamaruensis, and Chiasmolithus altus from the upper middle Eocene to lower Oligocene of Sites 647 and 748 , we document a complete gradation of forms among all three species. Chiasmolithus oamaruensis has significantly higher morphologic variance than the other species. The Chiasmolithus population at each site changes from $C$. expansus to $C$. oamaruensis and then to $C$. altus. This may not reflect a true evolutionary sequence because a major reversal in shape change of the central cross-bar structure accompanies this sequence, and because $C$. altus is morphologically closer to $C$. expansus than it is to $C$. oamaruensis. The change in the width of the cross-bar structure is primarily a result of changes in the alignment of the central connecting bar, rather than of changes in the cross-bar angle. At Site 748, two fluctuations in morphology produce sample populations intermediate between all three species. In addition, reported stratigraphic and paleogeographic occurrences of $C$. oamaruensis and $C$. altus show different latitudinal distributions. These morphological and distributional patterns may be explained by a continuous morphologic gradient between $C$. oamaruensis and $C$. altus, with $C$. oamaruensis occurring more commonly in cool-water paleoenvironments, and $C$. altus occurring more commonly in cold-water paleoenvironments. Thus, paleoenvironmental fluctuations at Site 748 may be the cause of the morphologic fluctuations in Chiasmolithus. This hypothesis can be tested against previously proposed evolutionary models by more detailed sampling of sections along a latitudinal transect.
\end{abstract}

\section{INTRODUCTION}

The abundance of microfossils in marine sediments makes them ideal for the study of evolution. Integrated biostratigraphies tied to the geochronologic time scale of Berggren et al. (1985) in many Cenozoic deep-sea cores provide the necessary framework for detailed studies on modes and rates of evolution as well as on paleobiogeography and biochronology. Many quantitative evolutionary studies have been done on planktonic foraminifers and radiolarians, but fewer on calcareous nannofossils. Among the latter, Backman (1980), Backman and Hermelin (1986), and Pujos (1987) used biometric analyses to understand taxonomic and evolutionary relationships among species of Coccolithus and Reticulofenestra. For the most part, such calcareous nannofossil studies have focused on species with fairly simple morphologies, that is, elliptical placoliths with simple holes in the center. In this paper, we present a preliminary study of a taxon with a more complicated morphology, the genus Chiasmolithus.

Common to abundant, well-preserved specimens of Chiasmolithus occur in complete middle Eocene to lower Oligocene sections at Ocean Drilling Program (ODP) Sites 647 $\left(53^{\circ} 19.9^{\prime} \mathrm{N}, 45^{\circ} 15.7^{\prime} \mathrm{W}\right.$; Labrador Sea, Fig. 1) and 748 $\left(58^{\circ} 26.45^{\prime} \mathrm{S}, 78^{\circ} 58.89^{\prime} \mathrm{E}\right.$; Kerguelen Plateau, southern Indian Ocean, Fig. 2). These provided an opportunity to study the transition from Chiasmolithus expansus in the middle Eocene

\footnotetext{
${ }^{1}$ Wise, S. W., Jr., Schlich, R., et al., 1992. Proc. ODP, Sci. Results, 120: College Station, TX (Ocean Drilling Program).

2 Department of Geology, Florida State University, Tallahassee, FL 32306, U.S.A. (present address: Ocean Drilling Program, 1000 Discovery Drive, Texas A\&M University Research Park, College Station, TX 77845, U.S.A.).

${ }^{3}$ Department of Geology, Florida State University, Tallahassee, FL 32306, U.S.A.
}

to Chiasmolithus oamaruensis and Chiasmolithus altus in the upper Eocene and Oligocene.

\section{DESCRIPTION OF CHIASMOLITHUS}

The genus Chiasmolithus was erected by Hay et al. (1966) to include elliptical placoliths with large central holes with an X or modified X-type structure made of cross-bars. Gartner (1970) studied the genus in detail with the transmission electron microscope to discern the phylogenetic relationships between the various species on the basis of their ultrastructures. He listed six characteristics by which species of the genus have been distinguished: size of the placolith, number of elements in the distal shield, the curvature of the elements, the size of the central opening, the shape of the cross-bars, and the presence of accessory structures (Fig. 3). To these he added the ultrastructure of the cross-bars. By light and electron microscope analysis, he separated the genus into two subcategories: species with cross-bars composed of axially aligned calcite laths on the distal side and transversely arranged calcite laths on the proximal side; and species with cross-bars composed of tabular calcite prisms. The first group shows axial sutures down the middle of the cross-bars under light microscopy, whereas the second group does not. Within the first group Gartner (1970) included Chiasmolithus bidens, C. grandis, C. expansus, and C. oamaruensis. Gartner (1970, p. 939) stated that these species "constitute a clearly defined lineage."

Perch-Nielsen (1985, p. 461) also separated the genus into two subgroups, similar to those of Gartner (1970). In the first group, she also included Chiasmolithus altus (Bukry and Percival, 1971). Perch-Nielsen (1985) stated that "C. oamaruensis has a very narrow central $\mathrm{X}$, which can pose problems in distinguishing it from $C$. expansus . . . (which has) a wider, but equally symmetrical central X. C. altus has a relatively 


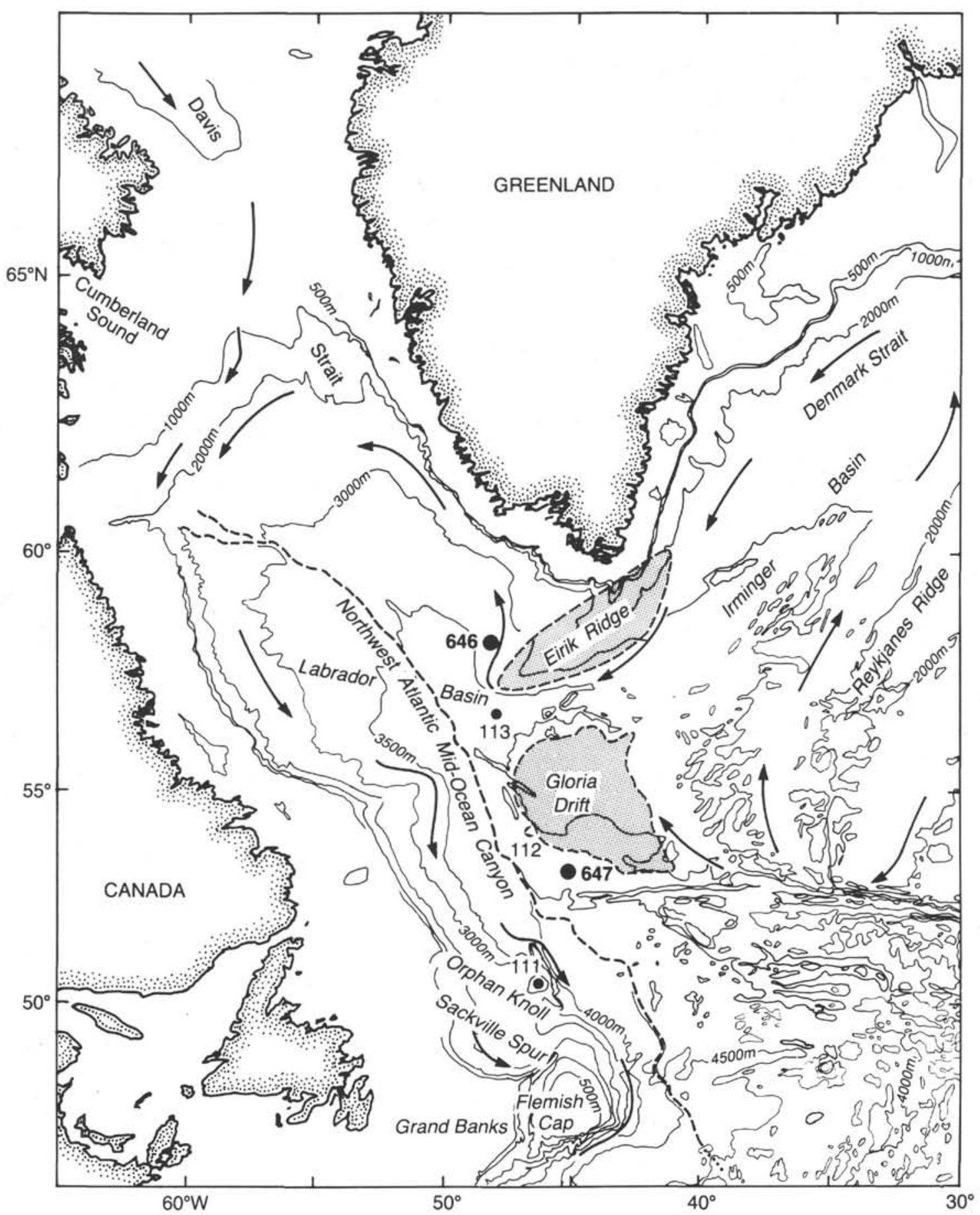

Figure 1. Map of the Labrador Sea illustrating the locations of Sites 647 and 646 and previously drilled DSDP Sites 111, 112 , and 113 .

small central area and a central cross with arms meeting at about right angles and of equal length."

Three upper middle Eocene to Oligocene species are Chiasmolithus expansus, $C$. oamaruensis, and $C$. altus. Their original descriptions are as follows:

Chiasmolithus oamaruensis (Deflandre in Deflandre and Fert, 1954, p. 146) Hay et al., 1966

"Elliptical, a little thick and slightly arched, with a wide margin and a border marked by fine superficial lines covering the margin; central hole crossed by a transversely disposed X. Holotype: length $17 \mu \mathrm{m}$, width $14 \mu \mathrm{m}$.

Other specimens: length 13-18 $\mu \mathrm{m}$." [translated from French]

Chiasmolithus expansus (Bramlette and Sullivan, 1961, p. 139-140) Gartner, 1970

"Coccoliths large, with closely appressed plates. Both outer and inner slopes of the upper plate narrow, the outer slope steep and slightly concave. Relatively large central opening transversely spanned by a wide, arching X-shaped structure. 


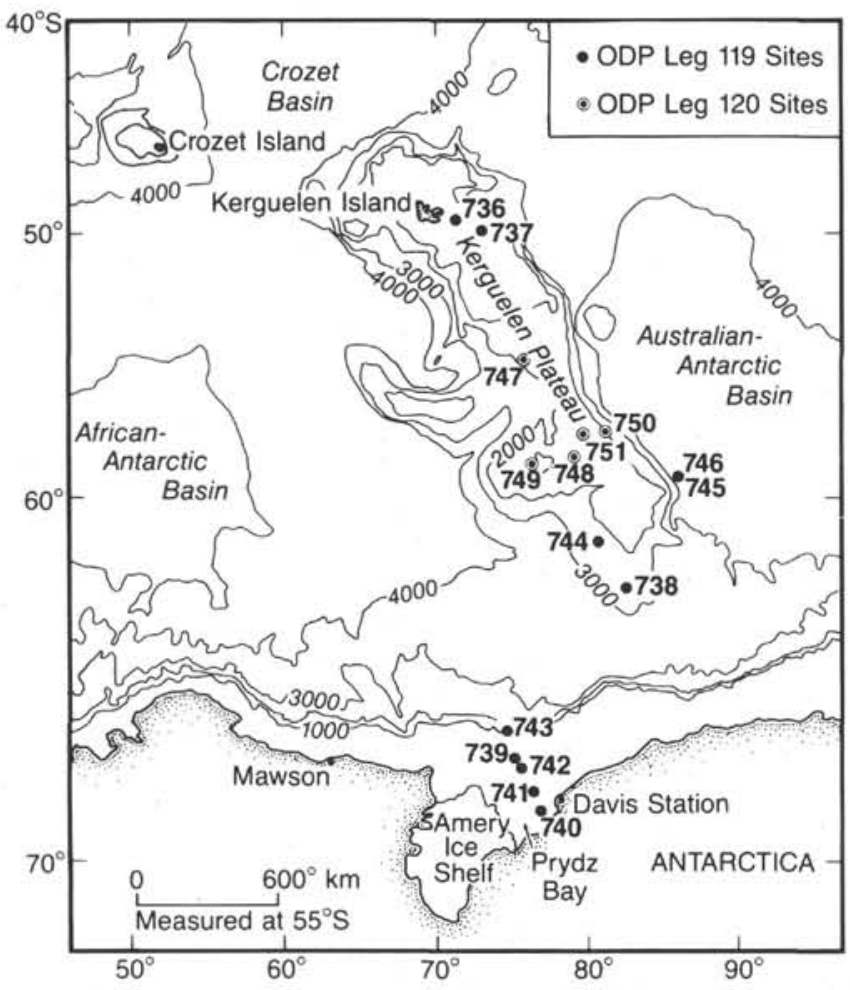

Figure 2. Map of the Kerguelen Plateau illustrating the locations of Site 748, other Leg 120 sites, and previously drilled Leg 119 sites.

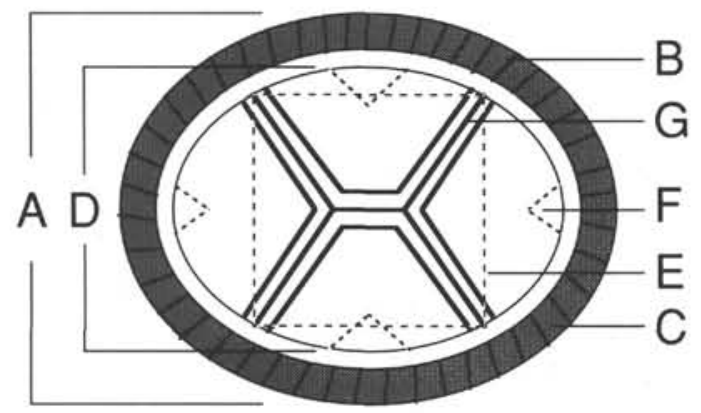

Figure 3. Parameters used to distinguish species of Chiasmolithus. A $=$ size of placolith, $\mathrm{B}=$ number of elements in distal shield, $\mathrm{C}=$ curvature of the elements, $\mathrm{D}=$ size of the central hole, $\mathrm{E}=$ shape of the crossbar structure, $\mathrm{F}=$ accessory structures, $\mathrm{G}=$ ultrastructure of cross-bars.

Length: $15-23 \mu \mathrm{m}$.

Remarks: These placoliths are distinctive in their large central opening as contrasted with the narrow surrounding rim. They differ from those of Coccolithus oamaruensis (Deflandre) . . . in having a more widely spread X-shaped structure with curved bars, and in the larger proportion of the central opening."

Chiasmolithus altus Bukry and Percival (1971, p. 126)

"This small elliptic species is characterized by an elliptic to oblong central opening that is spanned by a delicate $\mathrm{X}$-shaped cross-bar. Typically the bars meet at $90^{\circ}$ angles; on some specimens one set of bars is slightly offset. Measured along the short axis, the central area opening is equal to one third the total width of the coccolith. The rim is composed of about
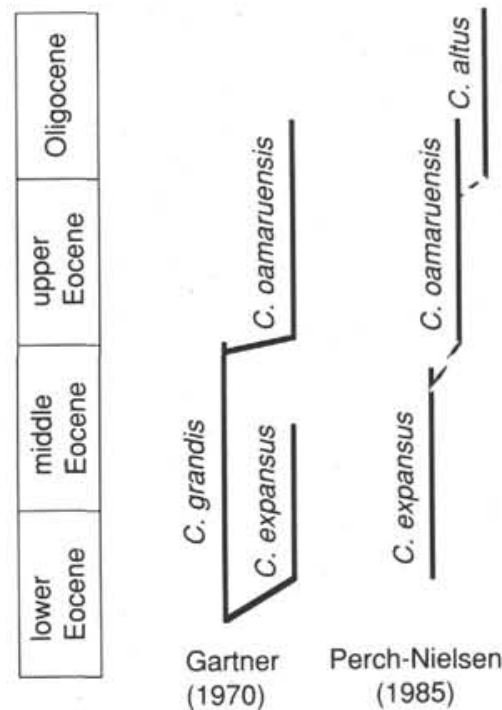

Figure 4. Proposed evolutionary lineages in the genus Chiasmolithus. Gartner (1970) on left; Perch-Nielsen (1985) on right.

60 elements and is faint in the outer portion in cross-polarized light.

Remarks: Chiasmolithus altus is distinguished from the similar species, Chiasmolithus oamaruensis (Deflandre), by the smaller central opening and crossbar angles of $90^{\circ}$. Chiasmolithus oamaruensis has a central opening equal to one half the coccolith diameter along the short axis and has crossbar angles of approximately $45^{\circ}$ and $135^{\circ}$. Chiasmolithus solitus (Bramlette and Sullivan) is about the same size as C. altus but has a narrower rim that is bright to the margin in crosspolarized light and the crossbar has one set of bars widely offset ...

Size: 10-18 $\mu \mathrm{m} . "$

The distinctions between $C$. expansus and $C$. oamaruensis are not clearly defined and are based on degrees of variation (e.g., smaller opening, wider central X). The definition of Bukry and Percival (1971) for C. altus is more restricted than the others, with absolute values for the cross-bar angles and relative hole size, allowing for little intraspecific variation in C. altus. Bukry and Percival (1971) also give a restricted definition for the shape of $C$. oamaruensis, in contrast with the original definition of Deflandre (in Deflandre and Fert, 1954).

Both Gartner (1970) and Perch-Nielsen (1985) proposed tentative evolutionary lineages for the species. Gartner (1970) showed $C$. oamaruensis and $C$. expansus as each developing separately from $C$. grandis, and with stratigraphic ranges that do not overlap (Fig. 4). Perch-Nielsen (1985) showed C. oamaruensis developing from $C$. expansus and tentatively giving rise to $C$. altus (Fig. 4). In her range chart (p. 458, fig. 19), however, she showed a gap between the highest occurrence (HO) of $C$. expansus (CP14a; NP16) and the lowest occurrence (LO) of C. oamaruensis.

Firth (1989b) and Wei et al. (this volume) documented the ranges of $C$. expansus, $C$. oamaruensis, and $C$. altus in upper middle Eocene to lower Oligocene sections from the Labrador Sea (Site 647) and the southern Indian Ocean (Site 748), respectively. At Site 647 , the range of $C$. expansus overlaps slightly with that of $C$. oamaruensis in the upper middle to lower upper Eocene, whereas $C$. altus occurs sporadically in the upper Eocene and more commonly in the Oligocene (Fig. 5). At Site 748, $C$. expansus overlaps with both $C$. oamaruensis and $C$. 


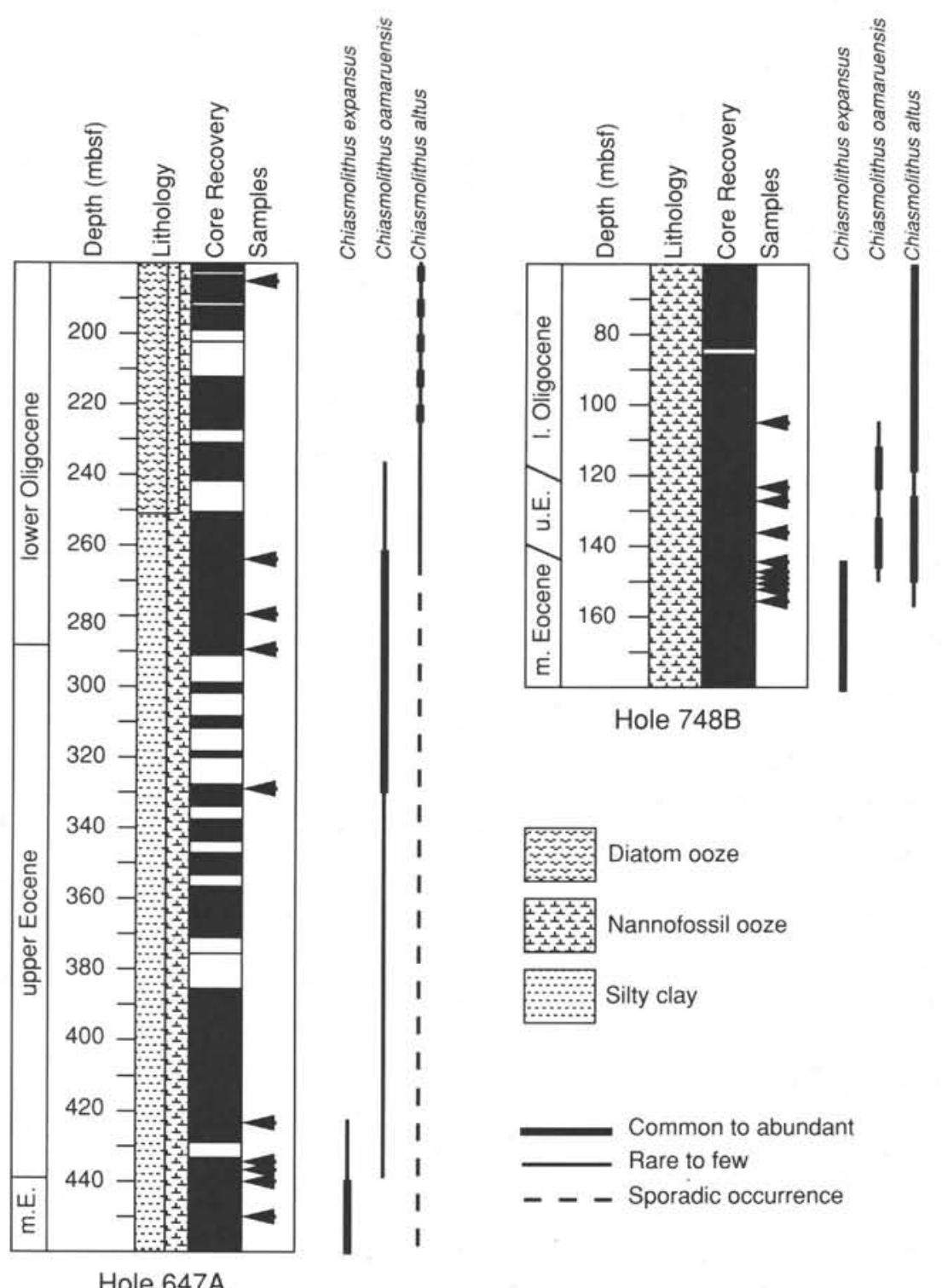

Figure 5. Lithology and core recovery of middle Eocene to lower Oligocene sediments drilled in Hole 647A (Labrador Sea) and Hole 748B (Kerguelen Plateau). Arrows show the locations of samples used to analyze Chiasmolithus. Ranges and abundances of $C$. expansus, C. oamaruensis, and C. altus from Firth (1989b) for Hole 647A and from Wei et al. (this volume) for Hole 748B.

altus in the upper middle to lower upper Eocene, and C. altus is much more abundant through the upper Eocene than at Site 647 (Fig. 5). The moderate to good preservation of the nannofossil assemblages and fairly good bio- and magnetostratigraphic age control for these two sites provides a good framework for an initial study of the evolutionary relationships of $C$. expansus, $C$. oamaruensis, and $C$. altus.

We will address several questions in this paper, as follows.

1. Are there natural, rather than arbitrary, morphologic breaks between the three species whereby clear lines of separation can be recognized? If so, what are the parameters and the values of the parameters that define the morphologic boundaries between species?

2. Do the original definitions of the three species reflect natural morphological variance?
3. What is the mode of evolution from $C$. expansus to the two younger species, and what is the nature of the evolutionary relationship between $C$. oamaruensis and $C$. altus (i.e., do these species represent a single gradually changing phyletic lineage, or is there one or more cladogenetic events whereby descendant forms branch off from the ancestral lineage and form separate morphologic lineages)?

4. Do environmental factors contribute to the distributions and evolutionary relationships of the three species?

We used biometric analysis of the species using the light microscope, measured the morphologic parameters of all specimens of Chiasmolithus in sample populations without subjective categorizations, and then used the morphological distribution patterns to address our specific questions. Accessory structures do not occur in these species, and the ultra- 
Table 1. List of each species of Chiasmolithus and intermediate forms, Sites 647 and 748.

\begin{tabular}{|c|c|c|c|c|c|c|c|}
\hline \multirow{2}{*}{$\begin{array}{l}\text { Core, section, } \\
\text { interval }(\mathrm{cm})\end{array}$} & \multirow{2}{*}{$\begin{array}{l}\text { Depth } \\
\text { (mbsf) }\end{array}$} & \multirow{2}{*}{$\begin{array}{l}\text { Age } \\
\text { (Ma) }\end{array}$} & \multirow{2}{*}{$\begin{array}{l}\text { Sample } \\
\text { label }\end{array}$} & \multicolumn{4}{|c|}{ Species (\%) } \\
\hline & & & & $\overline{\mathrm{E}}$ & 0 & A & I \\
\hline \multicolumn{8}{|l|}{$105-647 \mathrm{~A}-$} \\
\hline $20 \mathrm{R}-1,106-108$ & 184.6 & 32.1 & $\mathbf{J}$ & 2 & & 98 & \\
\hline $28 \mathrm{R}-3,71-73$ & 263.8 & 35.7 & I & 2 & 92 & 6 & \\
\hline $30 \mathrm{R}-1,16-18$ & 279.6 & 36.3 & H & & 100 & & \\
\hline $31 \mathrm{R}-1,4-6$ & 328.0 & 36.7 & G & & 100 & & \\
\hline $35 \mathrm{R}-1,36-38$ & 328.0 & 38.1 & F & & 100 & & \\
\hline $44 \mathrm{R}-6,100-102$ & 423.0 & 41.2 & E & 16 & 78 & & 6 \\
\hline $46 \mathrm{R}-1,101-103$ & 434.8 & 41.8 & D & 20 & 74 & & 6 \\
\hline $46 \mathrm{R}-3,33-35$ & 437.1 & 41.9 & C & 94 & 4 & & \\
\hline $46 \mathrm{R}-5,101-103$ & 440.8 & 42.2 & B & 92 & 4 & & \\
\hline $47 \mathrm{R}-5,43-45$ & 449.9 & 42.7 & A & 96 & & & 4 \\
\hline \multicolumn{8}{|l|}{$120-748 \mathrm{~B}-$} \\
\hline $13 \mathrm{H}-1,10-11$ & 104.7 & 32.9 & 10 & 2 & 50 & 48 & \\
\hline $14 \mathrm{H}-7,9-10$ & 123.2 & 37.8 & 9 & & 100 & & \\
\hline $15 \mathrm{H}-3,10-11$ & 126.7 & 38.4 & 8 & 22 & 48 & 20 & 8 \\
\hline $16 \mathrm{H}-3,10-11$ & 136.2 & 39.2 & 7 & & 100 & & \\
\hline $17 \mathrm{H}-2,10-11$ & 144.2 & 40.4 & 6 & & 100 & & \\
\hline $17 \mathrm{H}-4,10-11$ & 147.2 & 40.7 & 5 & 16 & 72 & 4 & 6 \\
\hline $17 \mathrm{H}-5,10-11$ & 148.7 & 40.8 & 4 & 32 & 54 & 6 & 6 \\
\hline $17 \mathrm{H}-6,10-11$ & 150.2 & 40.9 & 3 & 18 & 76 & & 6 \\
\hline $17 \mathrm{H}-7,10-11$ & 151.7 & 41.0 & 2 & 8 & 86 & & 6 \\
\hline $18 \mathrm{H}-3,10-11$ & 155.2 & 41.6 & 1 & 94 & 6 & & \\
\hline
\end{tabular}

Note: $\mathrm{E}=C$. expansus, $\mathrm{O}=C$. oamaruensis, $\mathrm{A}=C$, altus, and $\mathrm{I}=$ intermediates.

structure of the cross-bars are the same (Gartner, 1970). The number and curvature of the shield elements of these species were not mentioned in the original descriptions, nor have they been used to distinguish among them. Of the seven criteria that Gartner (1970) outlined for distinguishing species of the genus, three (placolith size, hole size, and shape of the cross-bars) are important in differentiating $C$. expansus, $C$. oamaruensis, and $C$. altus.

\section{METHODS}

For this preliminary study of the Chiasmolithus group, ten samples each were selected for analysis from Sites 647 and 748 (Table 1 and Fig. 5). Each sample from Site 647 was assigned a letter code (A through $\mathrm{J}$ ), and each sample from Site 748 was assigned a number code (1 through 10) to help us display the results in the figures (Table 1). The samples were chosen based first on the abundance of Chiasmolithus spp. in the sample (as this varied through each section), and second on the best preservation of the Chiasmolithus group (even moderately preserved nannofossil assemblages may have Chiasmolithus specimens with their central cross-bars broken or dissolved). The upper middle Eocene to lower upper Eocene appears to be a crucial interval for the change from Chiasmolithus expansus to the other two species; thus, more samples were chosen from this interval. These criteria resulted in uneven sample spacing both in hole depth and time.

Each sample listed in Table 1 was assigned an age based on age/depth curves constructed from integrated biostratigraphic and magnetostratigraphic datums. The datums and age/depth curve for Site 647 are taken from Firth (1989b), Shipboard Scientific Party (1987), and Clement et al. (1989) and are presented in Table 2 and Figure 6. Magnetostratigraphic datums are scarce in this section because of rotary drilling. We considered the first occurrence (FO) of Sphenolithus ciperoensis and the last occurrence (LO) of Coccolithus formosus to be reliable tie-points for the age/depth curve in the Oligocene because of their geochronologic reliability (Wei and Wise, 1989). Reticulofenestra umbilica shows a marked decrease in abundance above the LO of $C$. formosus, associated with a lithologic change, and before its final extinction
Table 2. List of biostratigraphic and paleomagnetic datums used to construct the age/depth curve for Hole 647A.

\begin{tabular}{|c|c|c|c|}
\hline Datum & $\begin{array}{l}\text { Depth } \\
\text { (mbsf) }\end{array}$ & $\begin{array}{l}\text { Age } \\
\text { (Ma) }\end{array}$ & Reference \\
\hline LO $S$. ciperoensis $(\mathrm{N})$ & 147.0 & 30.3 & 1 \\
\hline HO $G$. angiporoides (F) & 190.0 & 32.0 & 2 \\
\hline HO $R$, umbilica $(\mathrm{N})$ & 214.0 & 34.6 & 1 \\
\hline HO C. reticulata (D) & 222.0 & 34.0 & 2 \\
\hline LO C. reticulata (D) & 239.0 & 36.2 & 2 \\
\hline HO C. formosus (N) & 251.0 & 35.1 & 1 \\
\hline HO D. saipanensis $(\mathrm{N})$ & 289.0 & 36.7 & 1 \\
\hline HO $G$. linaperta $(\mathrm{F})$ & 291.0 & 36.7 & 2 \\
\hline HO $T$. cerroazulensis $(\mathrm{F})$ & 299.0 & 36.7 & 2 \\
\hline HO $R$. reticulata $(\mathrm{N})$ & 309.7 & 37.6 & 1,3 \\
\hline HO N. truempyi $(\mathrm{F})$ & 385.0 & 38.5 & 2 \\
\hline Top Chron C17 Normal (M) & 400.0 & 39.8 & 4 \\
\hline LO 1 . recurvus $(\mathrm{N})$ & 437.1 & 39.5 & 1,3 \\
\hline LO $C$. oamaruensis $(\mathrm{N})$ & 437.1 & $39.8-40.4$ & 1,3 \\
\hline Base Chron C18 Normal (M) & 453.0 & 42.8 & 4 \\
\hline HO C. solitus $(\mathrm{N})$ & 453.0 & 40.6 & 1,3 \\
\hline HO Acarinina (F) & 472.5 & 40.6 & 2 \\
\hline Top Chron C19 Normal (M) & 482.5 & 43.6 & 4 \\
\hline Base Chron C19 Normal (M) & 490.5 & 44.1 & 4 \\
\hline
\end{tabular}

Notes: Ages for datums are from Berggren et al. (1985), except for those that are from 3 (=Wei and Wise, 1989). Datums are from 1 = Firth (1989b), 2 = Shipboard Scientific Party (1987), and $4=$ Clement et al. (1989). $\mathrm{N}=$ calcareous nannofossils, $\mathrm{F}=$ foraminifers, $\mathrm{D}=$ diatoms, and $\mathrm{M}=$ paleomagnetism.

\section{Age (Ma)}

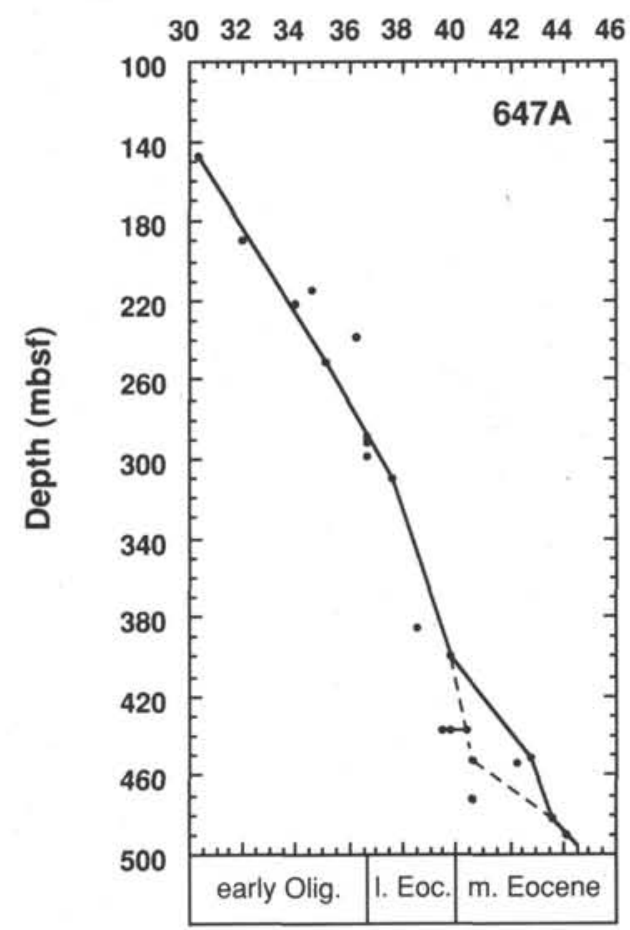

Figure 6. Age/depth curve for Hole 647A. Solid line represents the curve used for calculating ages of samples. Dashed line represents possible alternate age/depth interpretation based on biostratigraphic datums. See Table 2 for list of datums.

(Firth, 1989b). This pattern, seen also by Wei and Wise (1989) in the Weddell Sea and by Backman (1987) in the South Atlantic, makes it difficult to distinguish the true LO of this species from reworked specimens; therefore, this datum was not considered as reliable for calculating the age/depth curve at Site 647. A change in magnetic inclination is reported by 


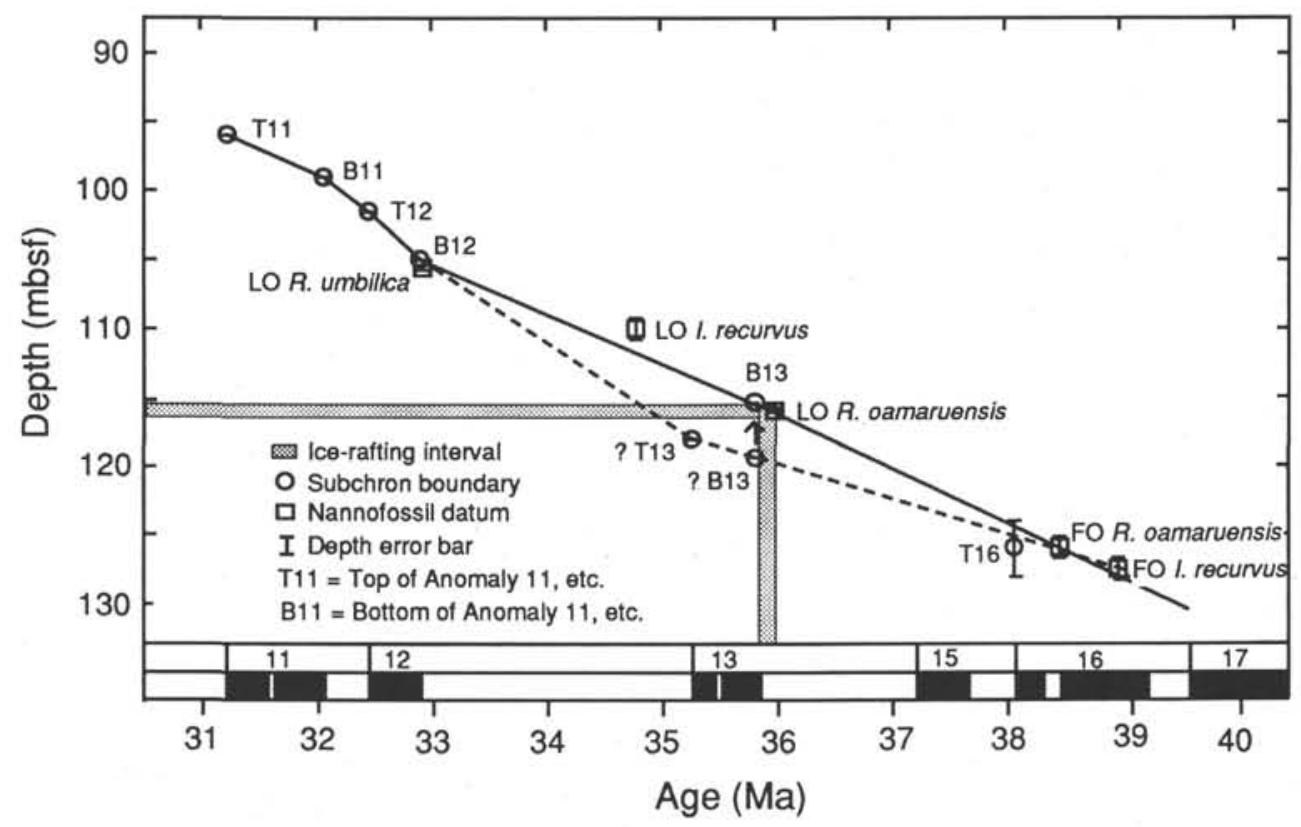

Figure 7. Age/depth curve for Hole 748B from Wei et al. (this volume).

Clement et al. (1989) at $400 \mathrm{~m}$ below seafloor (mbsf). This we interpret as representing the top of Chron $\mathrm{C} 17$. We also use the bottom of Chron C18 normal and the top and bottom of Chron C19 normal as tie-points, following the interpretation of Clement et al. (1989). Several calcareous nannofossil and planktonic foraminifer datums, however, do not agree with this interpretation. An alternate age/depth curve using these datums rather than that of Chron $\mathrm{C} 18$ normal, is shown by a dashed line (Fig. 6). This would indicate a lesser age than we have used for the five deepest samples studied at Site 647. The age/depth curve for Site 748 (Fig. 7), which has somewhat better magnetostratigraphic control because of piston coring, follows that of Wei et al. (this volume).

Smear slides were made from each sample. Random transects across each smear slide were made to select the first 50 horizontal, unobstructed, well-preserved specimens of Chiasmolithus. Each specimen was photographed by means of a Sony UP-811 video screen printer that was connected to a video camera mounted on a Zeiss Photomicroscope III. The high-quality images were measured with a digitizer.

Before measuring each specimen, we assigned it to one of four categories: $C$. expansus, $C$. oamaruensis, $C$. altus, or intermediate forms (Table 1). We performed this classification procedure to be able to relate the results of the biometric study (i.e., the values of scores in principal component space) to the species concepts as they are generally used. The observations and conclusions in this paper are based on the biometric analysis, not on this classification. The type descriptions of each species were used as guidelines to identify each specimen, and specimens that did not clearly fit into any species category were called "intermediate." End-member forms that closely resemble the holotypes of each species, are easily classified. Endmember forms of $C$. expansus show a central $\mathrm{X}$ that is much broader along the major axis of the placolith than along the minor axis (e.g., Plate 1, Fig. 13). End-member forms of $C$. oamaruensis have a central $\mathrm{X}$ that is much more narrow along the major axis of the placolith than along the minor axis (e.g., Plate 2, Fig. 12). End-member forms of $C$. altus have a central $\mathrm{X}$ that is symmetrical and has cross-bars at $90^{\circ}$ (e.g., Plate 1, Fig. 8 and Plate 2, Fig. 13) with very little or no offset. Forms that show morphologic variation away from the end-member forms are less easily classified. Our subjective classification is probably not completely reproducible, although it agrees well with the reported ranges and abundances of the three species by Firth (1989b) for Site 647 and by Wei et al. (this volume) for Site 748 . At each site, the oldest sample contains primarily Chiasmolithus expansus, the intermediate-age samples contain primarily $C$. oamaruensis, and the youngest sample contains primarily $C$. altus or a mix of $C$. oamaruensis and $C$. altus.

The eccentricity (length/width ratio) of Chiasmolithus has not been used to distinguish species differences, and it does not show noticeable changes in our samples. Therefore, we assumed that eccentricity is fairly constant and have chosen to measure only width of specimens to characterize their size. Likewise, we assumed that the eccentricity of the central hole was constant, and we have chosen to measure only the width of hole to characterize hole size. The type descriptions of the species compare the differences in relative, not absolute hole sizes; therefore, we use the ratio (hole width)/(overall width) to characterize relative hole size. We digitized 12 points on each specimen to derive the following parameters: overall width, width of hole, width of $\mathrm{X}$, length of X, width of central bar, and length of central bar (Fig. 8). These parameters are not good for an analysis of changes in shape because variations in their values caused by placolith shape change are compounded with variations caused by absolute size change. Therefore, we selected overall width to represent overall size change, and constructed the hole width/width ratio, $\mathrm{X}$ width/length ratio, central bar width/length ratio, and central bar width/hole width ratio to represent shape change.

We chose principal components analysis (PCA, using the program BMDP4M) as a data reduction method of the measured parameters and ratios to discern the relationships between the variables and to look for patterns of variation in the data. This analysis produces orthogonal principal component axes that explain $100 \%$ of the variation of the data in multivariate space. The data for both sites were combined in one 


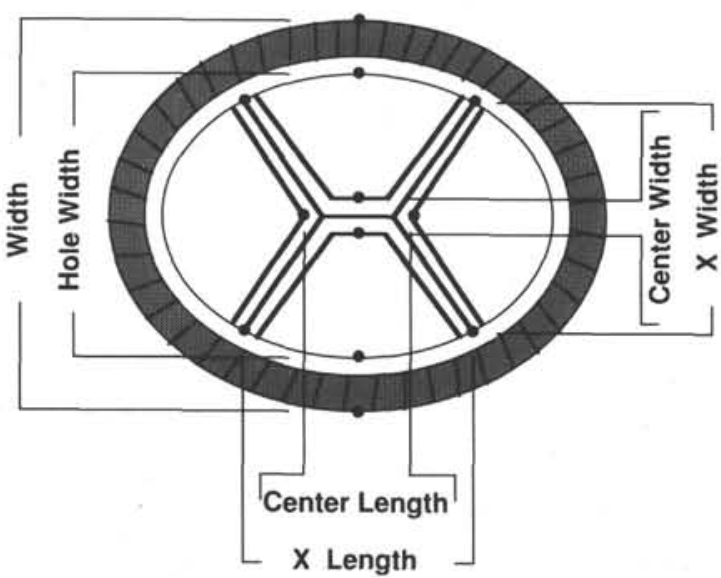

Figure 8. Diagram of a chiasmolith showing measurements used in the biometric analysis. Dots show the locations of the 12 points that were digitized to calculate the measurements.

analysis so that principal component scores could be compared between the two sites.

\section{RESULTS}

\section{Site 647}

The analysis produced two principal components (Table 3). The variables describing the cross-bar shape loaded heavily on Principal Component 1, whereas the variables describing size and relative hole size loaded heavily on Principal Component 2. Scatter plots of scores of all specimens at Site 647 (Fig. 9) show a complete range of morphological variation with no discernible gaps in morphologies. The greater density of points toward the $C$. expansus morphology is mainly because of the more frequent sampling in the middle Eocene. The outlines of the oldest (middle Eocene) sample, an earliest Oligocene sample, and the youngest (early Oligocene) sample show the morphological position and variance of end-member populations of $C$. expansus, $C$. oamaruensis, and $C$. altus, respectively. There is a full range of intermediate morphologies between these end-member forms.

Plots of principal component scores of all specimens in each sample at Site 647 (Fig. 10) show several interesting features: (1) every sample population appears unimodal (i.e., no bimodal distributions involving separate end-member groups are seen in any single sample); (2) overlaps in morphologies are seen between all adjacent samples; (3) the morphological variance is larger within samples that include end-member forms of $C$. oamaruensis, whereas samples containing end-member $C$. expansus and $C$. altus show smaller morphological variance; (4) the youngest samples of Oligocene age overlap considerably in morphology with the oldest samples of middle Eocene age.

The mean principal component scores for each sample from Site 647 (Table 4 and Fig. 11) are plotted to elucidate the morphologic change from sample to sample throughout the section. Arrows are included to show the sequence from the oldest sample to the youngest. This pattern shows an apparent pathway from $C$. expansus to $C$. oamaruensis to $C$. altus, with most of the morphologic change caused by differences in cross-bar shape and a lesser amount of change caused by differences in size and relative hole size. Samples D and E show positions intermediate between the end-member populations of $C$. expansus and C. oamaruensis, whereas Sample I is intermediate between $C$. oamaruensis and $C$. altus. This
Table 3. Results of principal component analysis (BMDP4M) of Chiasmolithus, Sites 647 and 748.

\begin{tabular}{|c|c|c|}
\hline $\begin{array}{l}\text { Principal } \\
\text { component }\end{array}$ & In data space & $\begin{array}{l}\text { In principal } \\
\text { component space }\end{array}$ \\
\hline \multicolumn{3}{|c|}{ Cumulative proportion of variance: } \\
\hline 1 & 0.462 & 0.637 \\
\hline 2 & 0.725 & 1.000 \\
\hline \multirow[t]{2}{*}{ Variable } & Principal & Principal \\
\hline & Component 1 & Component 2 \\
\hline \multicolumn{3}{|c|}{ Rotated loadings: } \\
\hline Width & -0.133 & 0.790 \\
\hline HWR & 0.125 & 0.823 \\
\hline $\mathrm{XR}$ & 0.902 & 0.084 \\
\hline $\mathrm{CR}$ & 0.926 & -0.021 \\
\hline CHR & 0.778 & -0.072 \\
\hline
\end{tabular}

Notes: $\mathrm{HWR}=$ hole width/width ratio, $\mathrm{XR}=\mathrm{X}$ length/width ratio, $\mathrm{CR}=$ central bar length/width ratio, $\mathrm{CHR}=$ central bar width/hole width ratio.

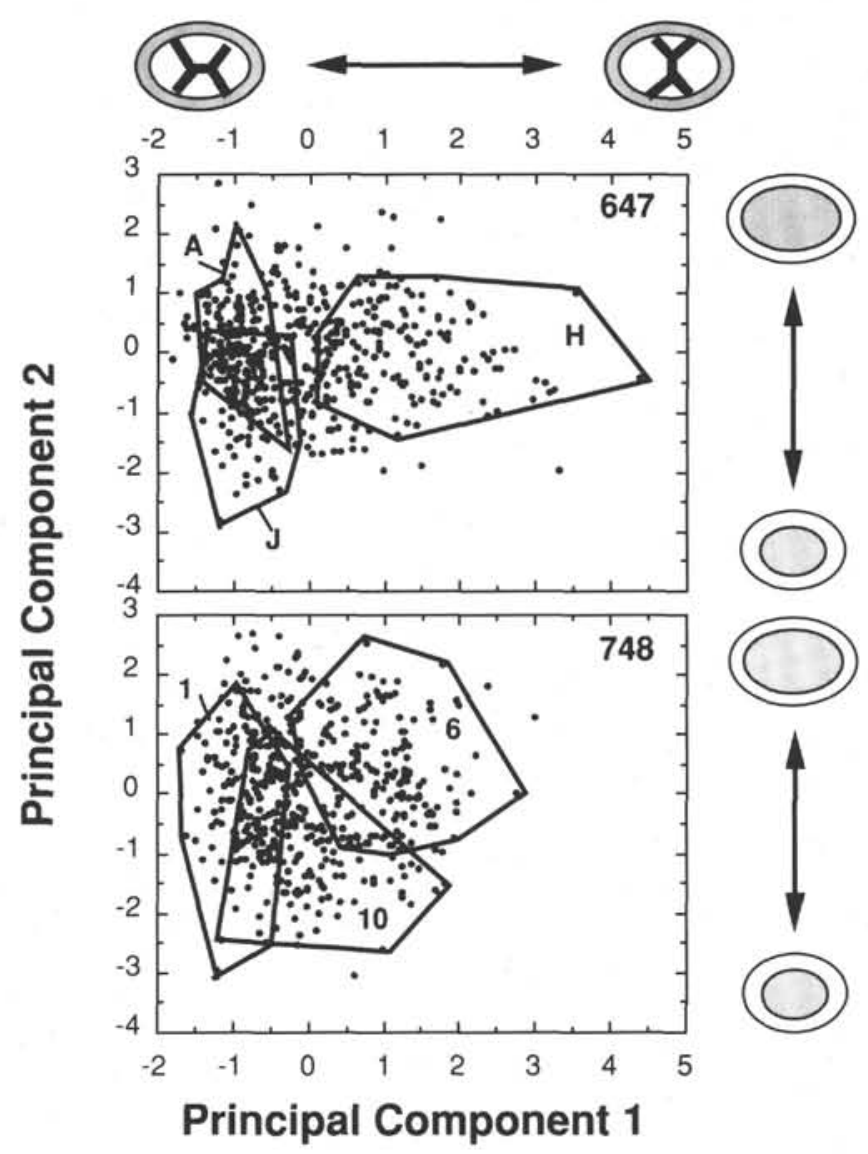

Figure 9. Plot of all measured specimens of Chiasmolithus in principal component space for Sites 647 and 748. Principal Component 1 represents a change in shape of the $\mathrm{X}$, with broader $\mathrm{X}$ shapes toward the negative principal component values and more narrow $\mathrm{X}$ shapes toward the positive principal component values. Principal Component 2 represents a change in overall width and relative width of the hole. Smaller specimens with smaller relative hole sizes have negative principal component values, whereas larger specimens with larger relative hole sizes have positive principal component values. Outlines of distribution of specimens in Samples A, H, and J at Site 647 and Samples 1, 6, and 10 at Site 748 illustrate the positions and amount of overlap of end-member populations of $C$. expansus, $C$. oamaruensis, and $C$. altus, respectively. 


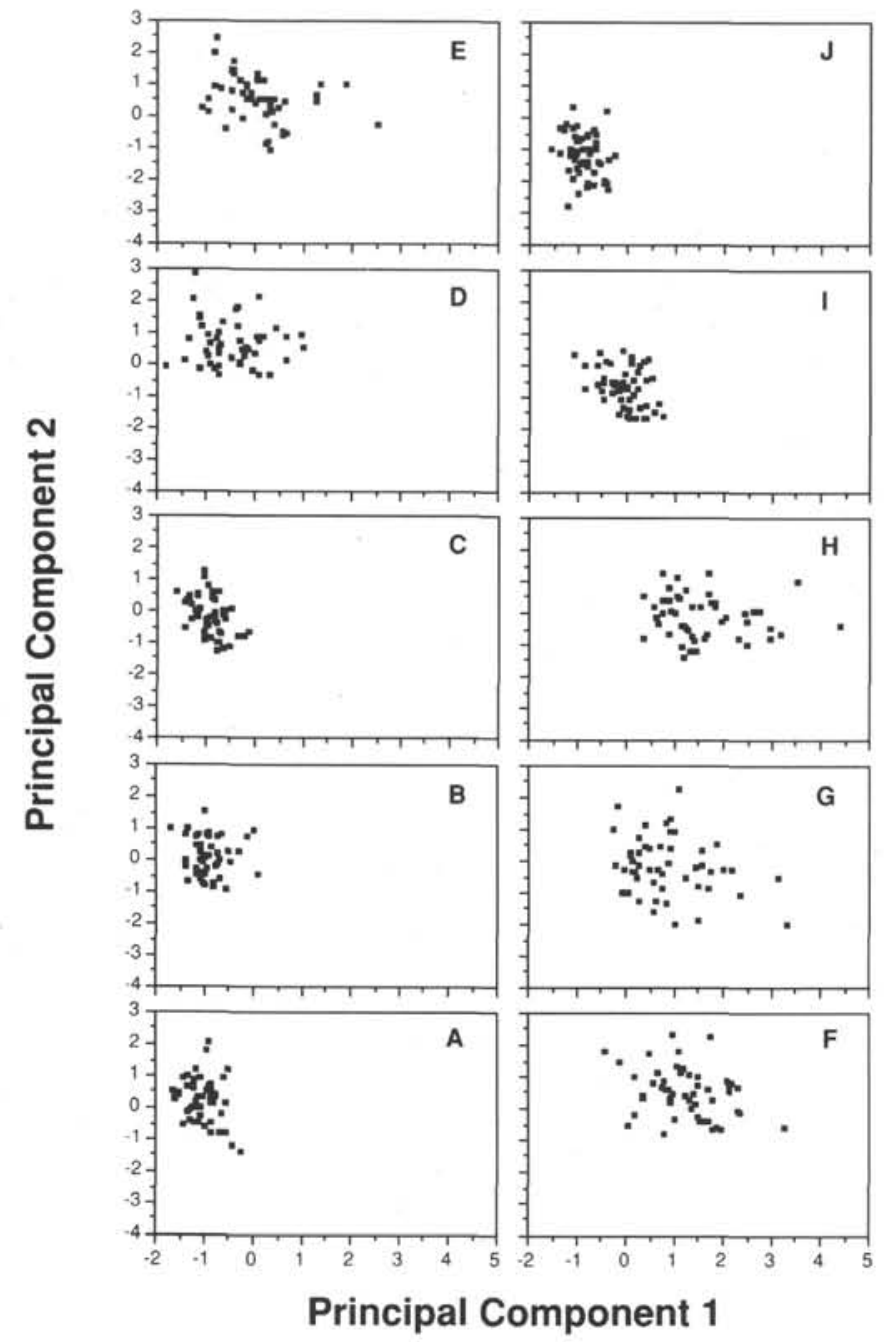

Figure 10. Plots in principal component space of Chiasmolithus specimens in each sample at Site 647 . Samples are identified by letters A through $\mathbf{J}$ (see Table 1).

explains the mixed species composition that we observed for these samples (Table 1). If this pattern reflects the true evolutionary development between the species, it would support the evolutionary lineage suggested by Perch-Nielsen (1985). Two features complicate this picture, however: (1) the morphological pathway shows a major reversal in cross-bar shape change in that it first becomes narrower toward $C$. oamaruensis and then becomes broader toward $C$. altus; (2) the youngest form, $C$. altus, is much closer morphologically to $C$. expansus than it is to $C$. oamaruensis. The overlap in morphology between $C$. expansus and $C$. altus suggests that they are more closely related evolutionally than would be the case if $C$. altus developed from $C$. oamaruensis. The intermediate samples (D, E, and I) are also not completely separate but do overlap with each other (Fig. 10).

We performed some basic statistical tests on the data to determine whether the pattern of change in principal component values from sample to sample was significant. First, we performed two-sided F-tests on selected sample pairs to see whether the variances in each sample are the same (Table 5). Samples separated primarily along the Principal Component 1 axis were tested with the Principal Component 1 sample variances. Likewise, samples separated primarily along the
Table 4. Mean principal component scores and standard deviations for samples from Sites 647 and 748.

\begin{tabular}{|c|c|c|c|c|c|c|}
\hline \multirow[b]{2}{*}{ Site } & \multirow[b]{2}{*}{ Sample } & \multicolumn{2}{|c|}{$\begin{array}{c}\text { Principal } \\
\text { Component } 1\end{array}$} & \multicolumn{2}{|c|}{$\begin{array}{c}\text { Principal } \\
\text { Component } 2\end{array}$} & \multirow[b]{2}{*}{$N$} \\
\hline & & Mean & SD & Mean & SD & \\
\hline 647 & J & -0.894 & 0.292 & -1.189 & 0.693 & 50 \\
\hline 647 & I & -0.059 & 0.402 & -0.671 & 0.626 & 50 \\
\hline 647 & $\mathrm{H}$ & 1.560 & 0.866 & -0.114 & 0.661 & 50 \\
\hline 647 & $\mathrm{G}$ & 0.906 & 0.853 & -0.161 & 0.931 & 50 \\
\hline 647 & $\mathrm{~F}$ & 1.276 & 0.720 & 0.501 & 0.779 & 50 \\
\hline 647 & E & 0.070 & 0.716 & 0.539 & 0.738 & 50 \\
\hline 647 & $\bar{D}$ & -0.472 & 0.625 & 0.648 & 0.692 & 50 \\
\hline 647 & $\mathrm{C}$ & -0.935 & 0.322 & -0.154 & 0.607 & 49 \\
\hline 647 & B & -0.912 & 0.353 & 0.089 & 0.605 & 48 \\
\hline 647 & A & -1.056 & 0.321 & 0.258 & 0.712 & 50 \\
\hline 748 & 10 & -0.009 & 0.625 & -1.212 & 0.824 & 50 \\
\hline 748 & 9 & 1.124 & 0.616 & 0.360 & 0.683 & 50 \\
\hline 748 & 8 & -0.490 & 0.440 & -0.515 & 0.947 & 50 \\
\hline 748 & 7 & 1.093 & 0.398 & -0.584 & 0.836 & 50 \\
\hline 748 & 6 & 1.093 & 0.525 & 0.808 & 0.854 & 50 \\
\hline 748 & 5 & -0.545 & 0.398 & 0.455 & 0.888 & 50 \\
\hline 748 & 4 & -0.574 & 0.422 & 0.258 & 0.891 & 50 \\
\hline 748 & 3 & -0.185 & 0.493 & -0.089 & 0.786 & 50 \\
\hline 748 & 2 & -0.055 & 0.454 & 1.294 & 0.822 & 50 \\
\hline 748 & 1 & -1.035 & 0.287 & -0.543 & 0.848 & 48 \\
\hline
\end{tabular}

Note: $\mathrm{SD}=$ standard deviation, and $N=$ number of samples studied.

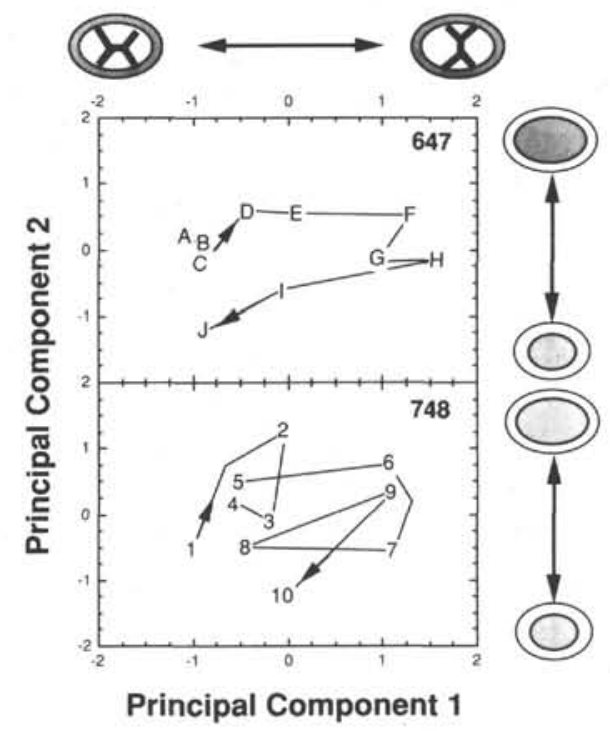

Figure 11. Plots of mean sample scores in principal component space for Sites 647 and 748. Arrows indicate the direction from the oldest sample to the youngest sample at each site.

Principal Component 2 axis were tested with the Principal Component 2 sample variances. Samples containing $C$. oamaruensis have significantly different variances at the $95 \%$ level from those containing $C$. expansus and $C$. altus. A plot of the sample means vs. sample variances for Principal Component 1 at Site 647 shows increased variance toward the C. oamaruensis morphology and decreased variance toward the $C$. expansus and $C$. altus morphologies (Fig. 12).

Based on these results, we assumed uncommon variance between samples and performed two-sided t-tests on selected sample pairs to see whether the respective mean principal component scores (for either principal component separately) are significantly different (Table 6). Most sample pairs were found to have significantly different means. The test for 
Table 5. Results of two-sided F-tests on selected sample pairs, Sites 647 and 748.

\begin{tabular}{|c|c|c|c|c|c|c|c|}
\hline \multirow[b]{2}{*}{ Samples } & \multirow{2}{*}{$\begin{array}{l}\text { Principal } \\
\text { component }\end{array}$} & \multirow[b]{2}{*}{$\mathrm{S}_{1}^{2} / \mathrm{S}_{2}^{2}$} & \multicolumn{2}{|c|}{$\mathrm{F}_{\alpha 2 \mathrm{~L}}$} & \multicolumn{2}{|c|}{$\mathrm{F}_{\alpha 2 \mathrm{U}}$} & \multirow[b]{2}{*}{ Reject? } \\
\hline & & & $\alpha=0.05$ & $\alpha=0.01$ & $\alpha=0.05$ & $\alpha=0.01$ & \\
\hline $\mathrm{A}, \mathrm{H}$ & 1 & 0.138 & 0.533 & 0.436 & 1.875 & 2.296 & Reject \\
\hline $\mathrm{J}, \mathrm{H}$ & 1 & 0.114 & & & & & Reject \\
\hline A, J & 1 & 1.210 & $n$ & $"$ & $"$ & " & Fail to \\
\hline $\mathrm{A}, \mathrm{J}$ & 2 & 1.058 & & & & & Fail to \\
\hline 1,6 & 1 & 0.299 & " & $"$ & " & " & Reject \\
\hline 6,10 & 1 & 1.418 & & & & & Fail to \\
\hline 1,10 & 1 & 0.211 & $n$ & " & " & " & Reject \\
\hline $1, \mathrm{~A}$ & 2 & 1.417 & & & & & Fail to \\
\hline $1, \mathrm{~J}$ & 2 & 1.499 & $"$ & " & $"$ & $"$ & Fail to \\
\hline
\end{tabular}

Notes: F-test, two-sided, reject if $\mathrm{S}_{1} 2 / \mathrm{S}_{2} 2<\mathrm{F}_{\alpha 2 \mathrm{U}}$ or $\mathrm{S}_{1} 2 / \mathrm{S}_{2} 2>\mathrm{F}_{\alpha 2 \mathrm{U}}$, degrees of freedom $=$ 40,40 .

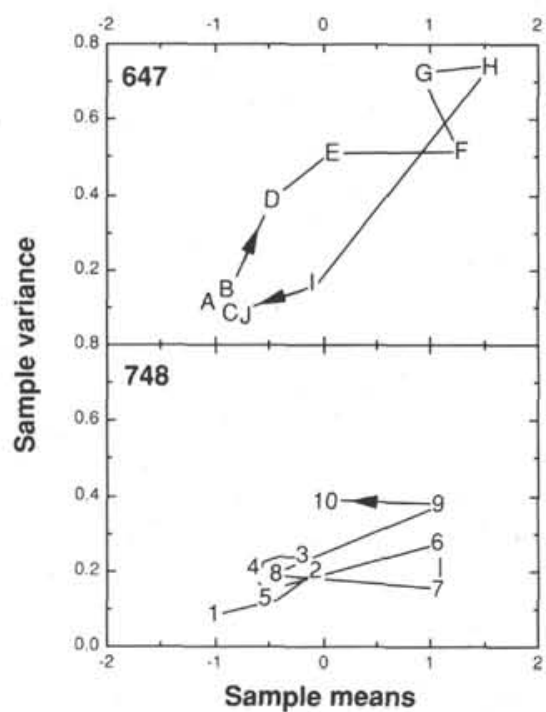

Figure 12. Sample mean scores vs. sample variances (Principal Component 1 ) for Sites 647 and 748 . Arrows indicate the direction from the oldest sample to the youngest sample at each site.

Samples B and C along Factor 2 barely failed to reject the null hypothesis at the $95 \%$ level. Thus, without rigorously testing every possible combination of sample pairs, it is fair to conclude that any two samples separated by a distance in principal component space similar to or less than that between Samples B and C should have sample means not significantly different at the $95 \%$ level. Sample means separated by a distance that is at least as far as Samples A and C should test significantly different at $95 \%$. Therefore, the overall pattern of change in mean principal component scores does reflect significant morphologic change in the Chiasmolithus populations.

\section{Site 748}

The distribution in principal component space of all specimens measured from Site 748 are shown in Figure 9. The oldest (middle Eocene) and youngest (early Oligocene) samples representing $C$. expansus and $C$. altus, and a sample of late middle Eocene age representing $C$. oamaruensis are outlined, similar to those outlined at Site 647 . Site 748 shows a closer distribution of points, with more overlap between the end-member samples and fewer extreme end-member forms of $C$. oamaruensis than at Site 647 . As at Site 647 , there is a continuous morphological spectrum without apparent gaps that clearly separate the end-member forms.
Table 6. Results of two-sided t-tests on selected sample pairs, Sites 647 and 748.

\begin{tabular}{|c|c|c|c|c|c|c|}
\hline \multirow[b]{2}{*}{ Samples } & \multirow{2}{*}{$\begin{array}{c}\text { Principal } \\
\text { component }\end{array}$} & \multirow{2}{*}{$\begin{array}{c}\text { Test } \\
\text { statistic }\end{array}$} & \multicolumn{2}{|c|}{$t_{\alpha 2 D}$} & \multirow[b]{2}{*}{ Reject? } & \multirow{2}{*}{$\begin{array}{l}\text { Degrees } \\
\text { of } \\
\text { freedom }\end{array}$} \\
\hline & & & $\alpha=0.05$ & $\alpha=0.01$ & & \\
\hline A, $\mathrm{H}$ & 1 & 13.784 & 2.009 & 2.678 & Reject & 50 \\
\hline $\mathrm{J}, \mathrm{H}$ & i & 18.989 & 2.000 & 2.660 & Reject & 60 \\
\hline A, J & 2 & 10.309 & 1.984 & 2.626 & Reject & 100 \\
\hline A, B & 2 & 1.264 & 1.987 & 2.632 & Fail to & 90 \\
\hline $\mathrm{A}, \mathrm{C}$ & 2 & 3.096 & 1.984 & 2.626 & Reject & 100 \\
\hline $\mathrm{B}, \mathrm{C}$ & 2 & 1.976 & 1.987 & 2.632 & Fail to & 90 \\
\hline 1,10 & 1 & 10.526 & 1.994 & 2.648 & Reject & 70 \\
\hline $\mathrm{A}, 1$ & 2 & 5.054 & 1.987 & 2.632 & Reject & 90 \\
\hline $1, \mathrm{~J}$ & 2 & 4.122 & 1.987 & 2.632 & Reject & 90 \\
\hline
\end{tabular}

Notes: t-test, two-sided, uncommon variance, reject if $|\mathrm{Y}| /\left(\mathrm{S}_{1} 2 / n_{1}+\mathrm{S}_{2} 2 / n_{2}\right)^{1 / 2}$ $>\mathrm{t}_{\alpha 2}$.

Scatter plots of each individual sample at Site 748 are shown in Figure 13. The same four features seen at Site 647 are also evident at Site 748 . One exception to this is that Sample 10, of early Oligocene age, does not show significantly smaller variance than late Eocene samples of $C$. oamaruensis. The position of this sample in principal component space approximates that of Sample I at Site 647. Sample I occupies an intermediate position between the $C$. oamaruensis endmember Sample $\mathrm{H}$ and the $C$. altus end-member Sample J. Sample 10, therefore, may not be truly representative of $C$. altus populations occurring throughout the lower to upper Oligocene at Site 748 (Wei et al., this volume). Samples younger than Sample 10 need to be analyzed to determine whether this is true.

The distribution pattern of the mean principal component values for each sample shows a more complicated pattern than that at Site 647 (Table 4 and Fig. 11). Beginning with the initial $C$. expansus population in Sample 1 , the samples sequentially shift toward the $C$. oamaruensis morphology, and then shift toward the $C$. altus population in Sample 10. A reversal in this pattern occurs between Sample 2 (intermediate between $C$. expansus and $C$. oamaruensis) and Sample 3, and a larger fluctuation occurs among Samples 7, 8, and 9. Sample 3, of middle Eocene age, occupies a position intermediate among the three end-member morphologies and contains specimens assignable to all three species. Sample 8, of late Eocene age, also occupies an intermediate position, albeit with more overlap with $C$. expansus and $C$. altus end-member populations than with $C$. oamaruensis. Similar fluctuations between $C$. oamaruensis and $C$. altus are independently reported in the same samples by Wei et al. (this volume).

Two-sided F-tests and two-sided t-tests were performed on selected sample pairs following the procedure for Site 647 


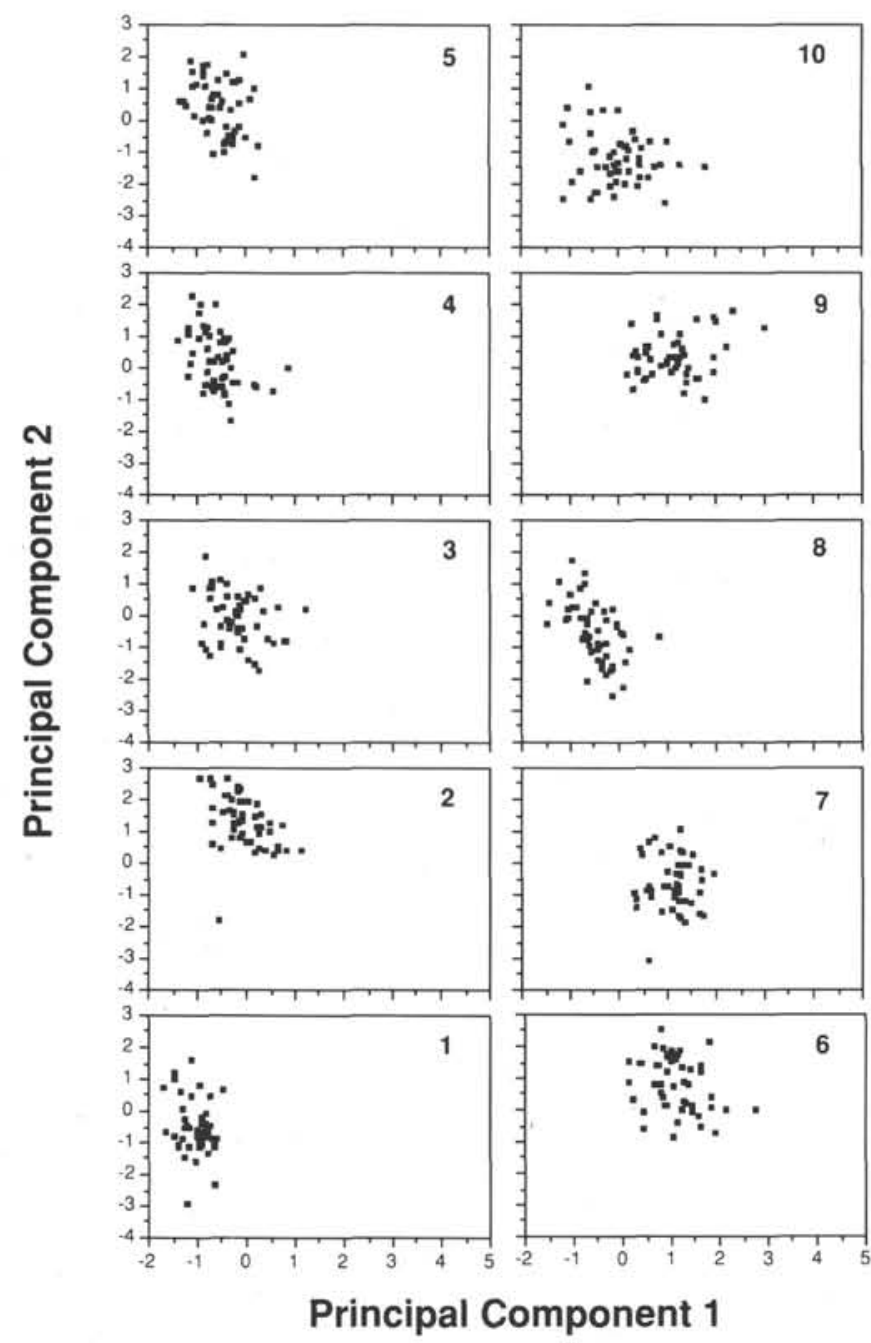

Figure 13. Plots in principal component space of Chiasmolithus specimens in each sample at Site 748. Samples are identified by numbers 1 through 10 (see Table 1).

(Tables 5 and 6). These show that the change in mean sample values at Site 748 represent significant morphologic change in the Chiasmolithus populations. The pattern of increased sample variance associated with the $C$. oamaruensis morphology and decreased sample variance associated with the $C$. expansus and C. altus morphologies is not as clearly seen at Site 748 as at Site 647 (Fig. 12). Samples 6 and 9 do show greater sample variances than most other samples; however, Sample 10 , with an intermediate morphologic position, also displays a large sample variance.

\section{DISCUSSION AND COMPARISON OF RESULTS}

At both sites, we see a complete spectrum of morphologies between extreme end-member forms of $C$. expansus, $C$. oamaruensis, and $C$. altus. The absence of discrete morphologic breaks between end-members, the presence of samples of intermediate morphologies, and the overlap in morphologies between all adjacent samples implies that definite parameters outlining natural boundaries between species cannot be established. Consequently, recognition of the range of occurrences of the three species is necessarily subjective and may vary among paleontologists. This may explain, in part, the variability seen in the range of $C$. oamaruensis reported by Wei and Wise (1989).
The small amount of variance in the $C$. altus population in Sample J supports a restricted definition for that species. Most specimens of $C$. altus, however, do not display the exact $90^{\circ}$ cross-bar angle or the exact relative hole size of one third the placolith size defined by Bukry and Percival (1971). The $C$. expansus sample populations also show a naturally small variance in the middle Eocene at both sites, which would support a restricted definition for that species. $C$. expansus, however, does not have a larger relative hole size than C. oamaruensis, as Bramlette and Sullivan (1961) indicate. The naturally larger variance of the $C$. oamaruensis morphology does not support the restricted definition of this species by Bukry and Percival (1971). Specimens with very narrow cross-bars and specimens of intermediate morphology with almost symmetrical cross-bars coexist. Paleontologists may, in practice, commonly group them all in the single species $C$. oamaruensis, rather than distinguish intermediate forms. The vague description of $C$. oamaruensis by Deflandre (in Deflandre and Fert, 1954), reflects the naturally large morphologic variance of this species.

More closely spaced sampling, as well as analysis of material at other localities, is needed before any conclusions can be made concerning the mode of evolution of these three species. This initial study does bring out some interesting features that may serve to direct future studies. The unimodal distributions in all samples indicate a lack of evidence for cladogenetic events between any of the species in these samples. Furthermore, extreme end-member species do not coexist; rather, intermediate samples contain intermediate morphologic distributions (e.g., Samples D, E, and I at Site 647 and Samples 2, 3, 8, and 10 at Site 748; Figs. 10 and 13). This argues against a model of two completely separate morphospecies co-occurring in the late Eocene to early Oligocene. Consequently, the reported cooccurrence of $C$. altus and $C$. oamaruensis throughout the upper Eocene at Site 748 by Wei et al. (this volume; also Fig. 5) may be interpreted as morphologically intermediate populations arbitrarily split into two species, rather than as the co-existence of two discrete end-member populations. Large fluctuations in the abundances of the two species reported by Wei et al. (this volume), however, are reflected by the morphologic shifts seen in Samples 3 and 8.

The existence of the $C$. altus morphology as part of the $C$. expansus populations in the middle Eocene at both sites, and the existence of sample populations intermediate between the three species in the middle and upper Eocene at Site 748 are not easily explained by a phyletic evolutionary lineage from $C$. expansus to $C$. oamaruensis to $C$. altus. Neither would the existence of such a lineage explain the occurrence of common $C$. altus and the paucity of $C$. oamaruensis through the upper Eocene at Sites 689 and 690 (Wei and Wise, 1990a). Possibly, different environmental factors at Sites 647 and 748 contributed to the different patterns of morphologic change seen at each site. If so, this could obscure the species true evolutionary pattern. Haq and Worsley (1982, fig. 1) pointed out the problem of mistaking the gradual replacement of one ecophenotypic variant of a species by another variant as an evolutionary change. Such a replacement pattern could be reversed several times as the environment fluctuated.

The stratigraphic distribution of the principal component values of each sample at both sites are plotted in Figure 14 along with oxygen isotopic data from Site 748 (Zachos et al., this volume). Wei et al. (this volume) consider population changes in cold-water nannofossil taxa to be more sensitive to surface-water temperature changes at Site 748 than the $\delta^{18} \mathrm{O}$ data. Therefore, the percent abundance of cold water taxa (Chiasmolithus spp., Isthmolithus recurvus, and Reticulofenestra daviesii, as determined by Wei and Wise, 1990b) 

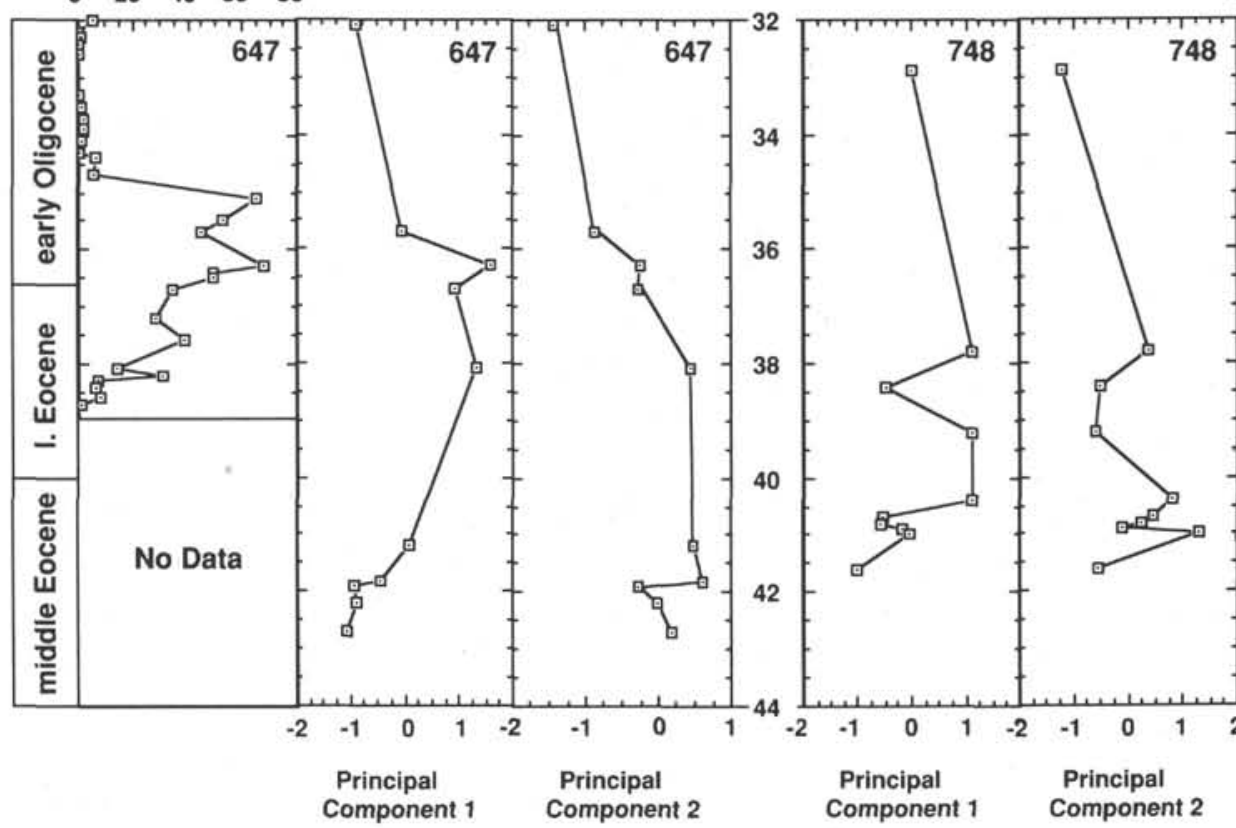

$\begin{array}{lllll}0 & 25 & 50 & 75 & 100\end{array}$

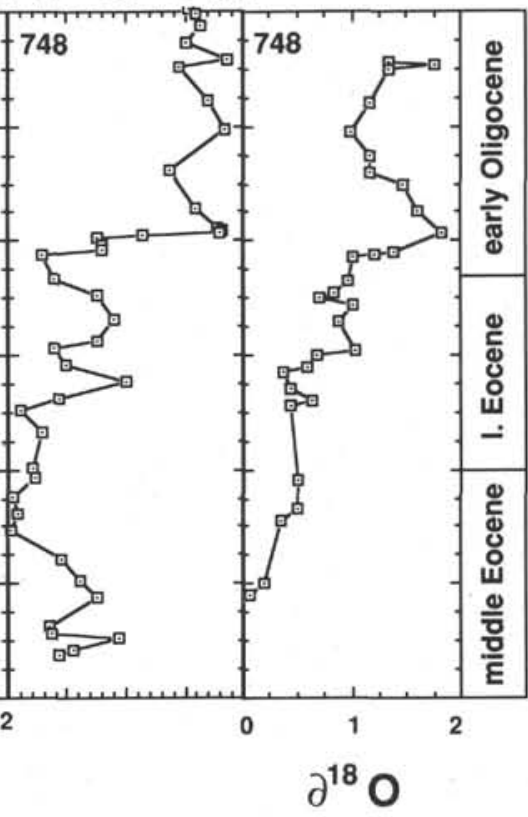

Figure 14. Mean principal component scores for each sample at Sites 647 and 748 plotted vs. age. Also shown is the percentage of cold-water taxa (Chiasmolithus spp., Isthmolithus recurvus, and Reticulofenestra daviesii) for Sites 748 (from Wei et al., this volume) and 647 . $\delta^{18} \mathrm{O}$ values for Site 748 from Zachos et al. (this volume).

calculated by Wei et al. (this volume) for Site 748 are also shown. We calculated similar percentage abundances of the same taxa, based on counts of 300 specimens per sample, for part of the section at Site 647.

Because the sample ages and spacing are unequal between sites, it is difficult to make direct comparisons of the two patterns of morphologic change. At Site 748, Samples 6, 7, and 9 , representing the $C$. oamaruensis morphology, coincide with low percentages of cold-water taxa, as well as $\delta^{18} \mathrm{O}$ values indicative of higher temperatures. The shifts toward a more intermediate and $C$. altus morphology in Samples 8 and 10 correspond to peaks in cold-water taxa. The ${ }^{818} \mathrm{O}$ curve suggests that a shift toward cooler temperatures occurred in the early Oligocene, but a similar shift is not recorded in upper Eocene Sample 8. This pattern might suggest that $C$. altus represents a colder water morphology, whereas $C$. oamaruensis represents a cooler (not necessarily warm) water morphology. Support for this interpretation may come from the reported distributions of these species (Fig. 15), where $C$. altus displays higher abundances and longer ranges than $C$. oamaruensis in the highest latitude sites. Wei and Wise (1990a) also observed this distributional pattern. At Site 647, however, the $C$. oamaruensis morphology corresponds to peaks in cold-water taxa in the upper Eocene and lower Oligocene-a relationship opposite of what the pattern at Site 748 might suggest. We need more detailed sampling in these sections as well as at other sections with good paleoenvironmental and stratigraphic control if we are to clarify the environmental affinities as well as the evolutionary relationship of $C$. expansus, $C$. oamaruensis, and $C$. altus.

\section{CONCLUSIONS}

A principal components analysis of Chiasmolithus from the upper middle Eocene to the lower Oligocene of Sites 647 and 748 revealed the following:
1. A complete intergradation of forms exists between $C$. expansus, $C$. oamaruensis, and $C$. altus. Changes in the population morphologies between adjacent samples are gradual and include transitional forms. No clear lines of separation can be made between the three species; therefore, differentiation between species remains largely subjective.

2. Morphologic variance within sample populations is significantly greater in C. oamaruensis than in C. expansus or C. altus. Consequently, significant morphologic changes from more intermediate sample populations to end-member populations of $C$. oamaruensis may be unrecorded because of a very broad species concept of $C$. oamaruensis. On the other hand, small but significant shifts in morphology away from the restricted end-member populations of $C$. expansus and $C$. altus may simply be recorded by paleontologists as increases in abundance of $C$. oamaruensis without mention of intermediate forms.

3. An apparent pattern of morphologic development from $C$. expansus to $C$. oamaruensis to $C$. altus at Site 647 may reflect the hypothetical evolutionary trend proposed by PerchNielsen (1985) for these species. However, a simple phyletic lineage, with $C$. oamaruensis occupying the intermediate position between the other two forms, does not easily explain the reversal in shape of the central X from $C$. expansus to $C$. oamaruensis to $C$. altus, or the close morphological similarity (and overlap) between $C$. altus and $C$. expansus seen at Sites 647 and 748 .

The absence of bimodal distributions in any sample does not support a cladogenetic model for the development of the two younger species from $C$. expansus, although more detailed sampling in these and other sites may provide evidence for such a model. The presence of morphologically intermediate populations at Site 748 in the middle and upper Eocene 

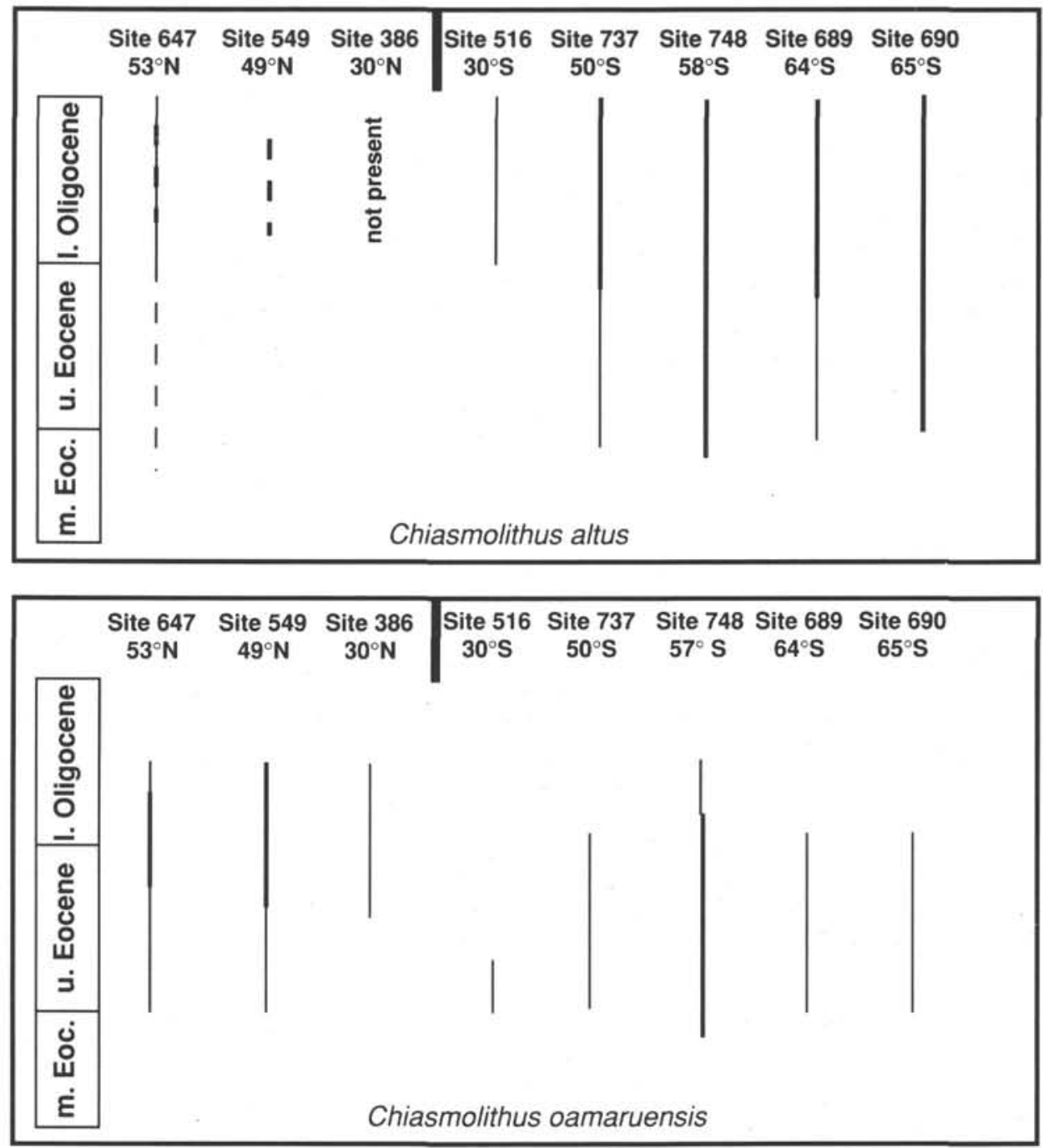

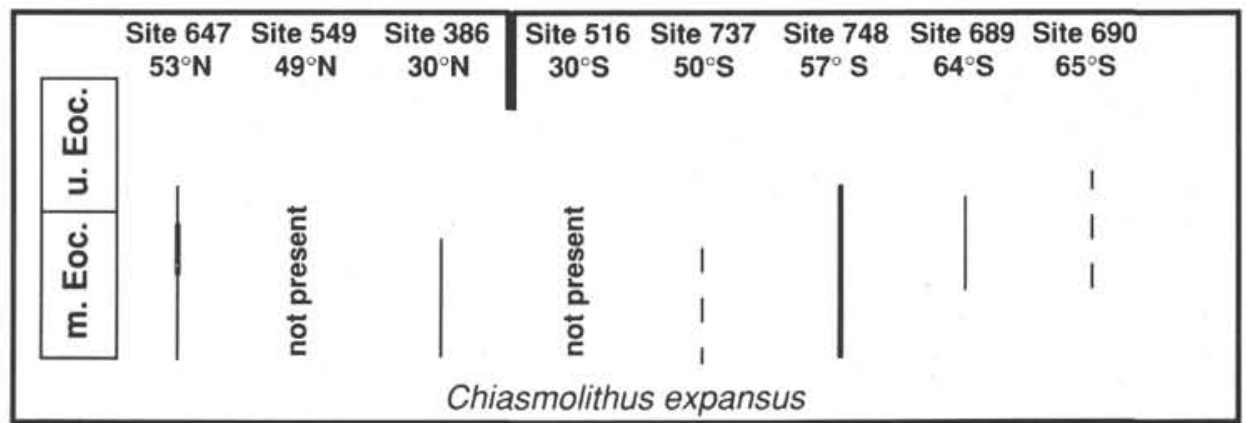

Figure 15. Reported ranges and abundances of C. expansus, C. oamaruensis, and C. altus at different latitudes. Data are taken from Site 647, Firth (1989b); Site 549, Müller (1985); Site 386, Okada and Thierstein (1979); Site 516, Wei and Wise (1989); Site 737, Wei and Thierstein (1991); Site 748, Wei et al. (this volume); Sites 689 and 690, Wei and Wise (1990a). Symbols for abundances are the same as for Figure 5 .

(Samples 3 and 8) and in the Oligocene of Site 647 (Sample I) suggests instead that a morphologic gradient may occur between the two younger species through their common range of occurrence (upper middle Eocene to lower Oligocene). The reported occurrences of $C$. altus and $C$. oamaruensis from different sites further suggests that the different morphologies have different latitudinal distributions. The $C$. altus morphol- ogy may reflect cold-water paleoenvironments, whereas the C. oamaruensis morphology may reflect cool-water paleoenvironments. This scenario is not yet fully demonstrable, as $C$. oamaruensis occurred during an apparent cold-water maximum at Site 647. Detailed sampling at several latitudinally separate sites should help clarify the mode of evolution displayed by the Chiasmolithus group in the upper Paleogene. 


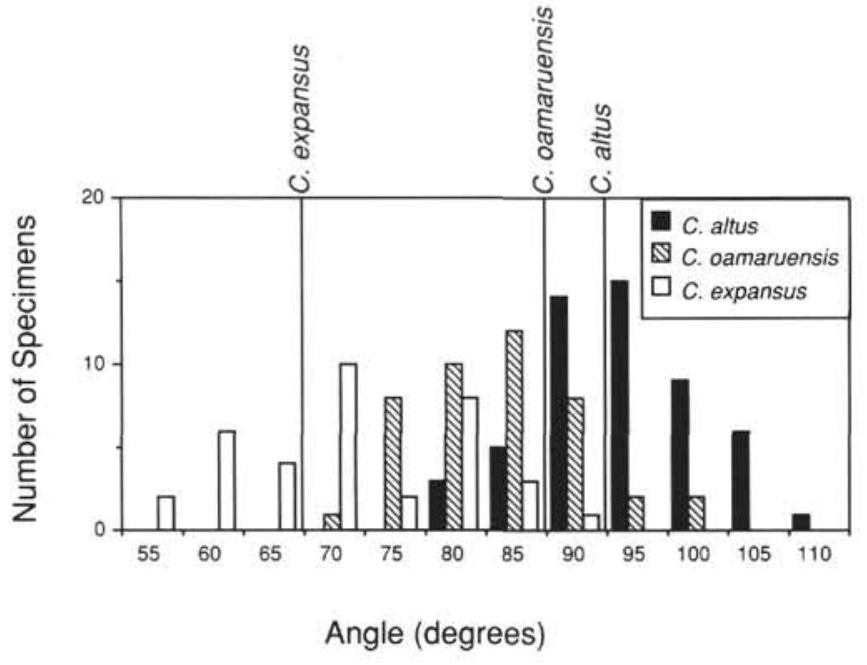

Figure 16. Frequency of specimens with different cross-bar angles bisected by the short axis of the placolith, for Samples A (Chiasmolithus expansus), $\mathrm{H}$ (Chiasmolithus oamaruensis), and J (Chiasmolithus altus). The cross-bar angles for the holotypes of the three species are marked by thin lines.

\section{SYSTEMATIC PALEONTOLOGY}

\author{
Genus Chiasmolithus Hay et al. (1966)
}

Chiasmolithus oamaruensis (Deflandre in Deflandre and Fert, 1954) Hay et al. (1966)

Chiasmolithus expansus (Bramlette and Sullivan, 1961) Gartner (1970)

Chiasmolithus altus Bukry and Percival (1971)

Discussion. According to the discussion in Bukry and Percival (1971), and to the schematic diagrams in Perch-Nielsen (1985, p. 461, fig. 22) of the cross-bar structures of the various species, the differences between the cross-bars of the three species are a result of changes in the angle at which they meet; that is, $C$. expansus has curved cross-bars with the acute angle bisected by the long axis of the placolith, $C$. oamaruensis has cross-bars with the acute angle bisected by the short axis of the placolith, and $C$. altus has cross-bars that meet at right angles. However, we measured the cross-bar angles from the published photographs of the holotypes of all three species and found somewhat different configurations for $C$. expansus and $C$. oamaruensis. In $C$. expansus, the acute angle (about $65^{\circ}$ ) is bisected by the short axis of the placolith and the obtuse angle (about $115^{\circ}$ ) is bisected by the long axis, whereas in $C$. oamaruensis the slightly acute angle (about $85^{\circ}$ ) is bisected by the short axis and the slightly obtuse angle (about $95^{\circ}$ ) is bisected by the long axis. The holotype of $C$. altus has approximately $90^{\circ}$ angles between cross-bars (Fig. 16).

Measurement of the angles of the three end-member samples from Site 647 (Fig. 16) gave the following mean angles bisected by the short axis of the specimens: Sample A (C. expansus $)=68.9^{\circ}$; Sample H $(C$. oamaruensis $)=81.1^{\circ}$; Sample $\mathrm{J}(C$. altus $)=92.3^{\circ}$. The angles between the cross-bars show a relationship opposite to that suggested by Perch-Nielsen (1985). In C. expansus, which has the widest central $\mathrm{X}$, the short axis of the placolith bisects the most acute angle of the three species, rather than the most obtuse angle. Therefore, the narrowing of the $\mathrm{X}$ is not caused by a shift toward more acute angles bisected by the short axis.

A reexamination of the cross-bar structures reveals a central bar that connects the cross-bars (Fig. 17). The orientation of this bar, either along the long axis or the short axis of the placolith, affects the width of the $X$. As the length of the bar shortens, the $X$ narrows, even without a change in the angles of the cross-bars (Fig. 17). When the central bar becomes equally as wide as it is long, the cross-bars meet at the center, as in C. altus. Further constriction of the central bar reverses the long and short axes, so that the cross-bars are separated by a bar parallel to the short axis of the placolith, as in $C$. oamar-
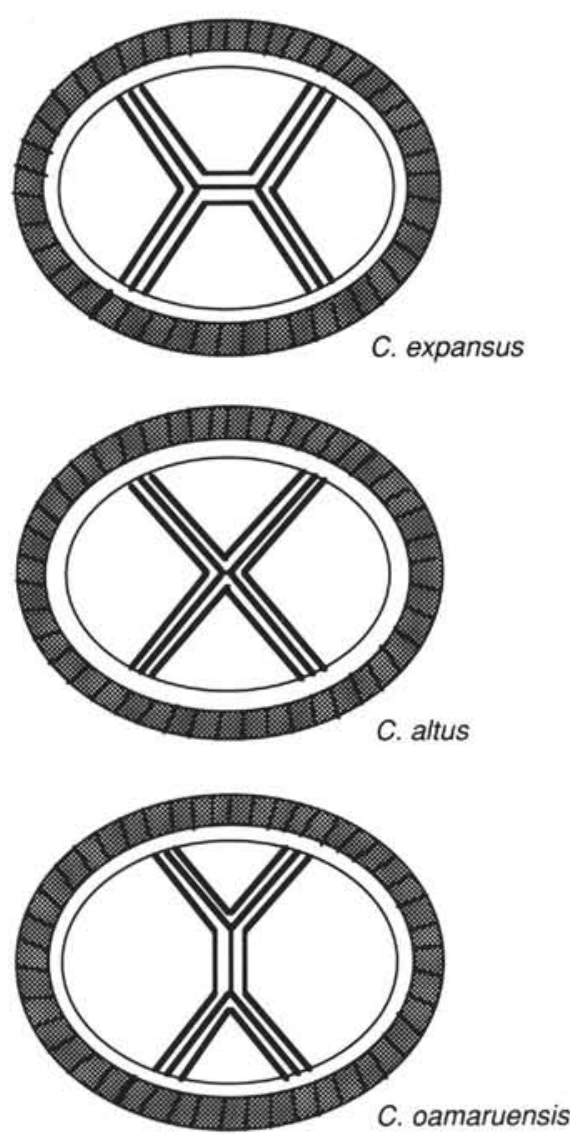

Figure 17. Change in the central bar structure from $C$. expansus (with central bar aligned along long axis) to $C$. altus (with little or no central bar) to $C$. oamaruensis (with central bar aligned along short axis). The change in the width of $\mathrm{X}$ is primarily the result of the change in the alignment of the central bar.

uensis. Thus, the $\mathrm{X}$ length/width ratio of the specimen is largely affected by the central bar length/width ratio.

Chiasmolithus altus differs from $C$. expansus in that it is generally smaller, has a smaller relative hole size, slightly shorter central bars, and cross-bar angles closer to $90^{\circ}$. Chiasmolithus oamaruensis differs from $C$. expansus by having a central bar parallel to the short axis rather than the long axis, and slightly more obtuse cross-bar angles bisected by the short axis. Chiasmolithus oamaruensis differs from $C$. altus by having generally larger relative hole sizes, central bars aligned along the short axis, and slightly more acute cross-bar angles bisected by the short axis. The curvature of the cross-bars noted by Bramlette and Sullivan (1961) for $C$. expansus occurs in some, but not in all, specimens of that species. In many specimens, including the holotype of $C$. expansus, small crystallites on the outer edges of the cross-bars will "round-off' the angles where the cross-bars meet both the central bar and the inner rim of the placolith. This lends an apparent curvature to the cross-bars although the central axes of the cross-bars are, in fact, straight. This apparent curvature of the cross-bars also is evident in many specimens of $C$. oamaruensis and C. altus.

Because of the presence of many intermediate forms, it is difficult to specify limits to the ranges of the parameters of each species so that they can be distinguished from one another. The definition of Bukry and Percival (1971) for $C$. altus as having a hole size one third the width of the placolith is too restricted in range. The mean hole width/placolith width ratio of Sample J (Site 647, C. altus) is 0.44 . The same ratio for Sample A (Site 647, C. expansus) is 0.50. A median cutoff value of 0.47 between them would not be practical, especially because the mean value for Sample 1 (Site 748, C. expansus) is 0.48 . Likewise, setting the limits for the $\mathrm{X}$ length/width and central bar length/width ratios would be arbitrary and not completely satisfac- 
tory. Although end-member forms can easily be separated, the presence of transitional forms suggests that the Chiasmolithus population of the upper Eocene to lower Oligocene, within the range of $C$. oamaruensis, should be treated as one variable complex.

\section{ACKNOWLEDGMENTS}

This research was derived from a Ph.D. dissertation by the senior author at Florida State University (Firth, 1989a). Support for this research was provided by a JOI/USSAC Ocean Drilling Fellowship and a FSU University Fellowship. Laboratory facilities were provided by a grant from the Amoco Foundation. The comments of two anonymous reviewers and of editorial board member Ellen Thomas helped improve this manuscript considerably.

\section{REFERENCES}

Backman, J., 1980. Miocene-Pliocene nannofossils and sedimentation rates in the Hatton-Rockall Basin, NE Atlantic Ocean. Stockholm. Contrib. Geol., 36:1-91.

1987. Quantitative calcareous nannofossil biochronology of middle Eocene through early Oligocene sediment from DSDP Sites 522 and 523. Abh. Geol. Bundensant. Austria, 39:21-31.

Backman, J., and Hermelin, J.O.R., 1986. Morphometry of the Eocene nannofossil Reticulofenestra umbilicus lineage and its biochronological consequences. Palaeogeogr., Palaeoclimatol., Palaeoecol., 57:103-116.

Berggren, W. A., Kent, D. V., and Flynn, J. J., 1985. Jurassic to Paleogene: Part 2. Paleogene geochronology and chronostratigraphy. In Snelling, N. J. (Ed.), The Chronology of the Geological Record. Geol. Soc. London Mem., 10:141-195.

Bramlette, M. N., and Sullivan, F. R., 1961. Coccolithophorids and related nannoplankton of the early Tertiary in California. Micropaleontology, 7:129-174.

Bukry, D., and Percival, S. F., 1971. New Tertiary calcareous nannofossils. Tulane Stud. Geol. Paleontol., 8:123-146.

Clement, B. M., Hall, F. J., and Jarrard, R. D., 1989. The magnetostratigraphy of Ocean Drilling Program Leg 105 sediments. In Srivastava, S. P., Arthur, M. A., Clement, B., et al., Proc. ODP, Sci. Results, 105: College Station, TX (Ocean Drilling Program), 583-595.

Deflandre, G., and Fert, C., 1954. Observations sur les coccolithophorids actuels et fossiles en microscopie ordinaire et lectronique. Ann. Paleontol., 40:115-176.

Firth, J. V., 1989a. Biometric analysis of Eocene and Oligocene calcareous nannofossils [Ph.D. dissert.]. Florida State Univ., Tallahassee.

, 1989b. Eocene and Oligocene calcareous nannofossils from the Labrador Sea, ODP Leg 105. In Srivastava, S. P., Arthur,
M. A., Clement, B., et al., Proc. ODP, Sci. Results, 105: College Station, TX (Ocean Drilling Program), 263-286.

Gartner, S., 1970. Phylogenetic lineages in the Lower Tertiary coccolith genus Chiasmolithus. North American Paleontol. Convention, Sept. 1969, Proc. G, 930-957.

Haq, B. U., and Worsley, T. R., 1982. Biochronology-biological events in time resolution, their potential and limitations. In Odin, G. S. (Ed.), Numerical Dating in Stratigraphy: New York (Wiley \& Sons), 19-36.

Hay, W. W., Mohler, H. P., and Wade, M. E., 1966. Calcareous nannofossils from Nal'chik (northwest Caucasus). Eclog. Geol. Helv., 59:379-399.

Müller, C., 1985. Biostratigraphic and paleoenvironmental interpretation of the Goban Spur region based on a study of calcareous nannoplankton. In Graciansky, P. C. de, Poag, C. W., et al., Init. Repts. DSDP, 80, Pt. 1: Washington (U.S. Govt. Printing Office), 573-599.

Okada, H., and Thierstein, H. R., 1979. Calcareous nannoplanktonLeg 43, Deep Sea Drilling Project. In Tucholke, B. E., Vogt, P. R., et al., Init. Repts. DSDP, 43: Washington (U.S. Govt. Printing Office), 507-573.

Perch-Nielsen, K., 1985. Cenozoic calcareous nannofossils. In Bolli, H. M., Saunders, J. B., and Perch-Nielsen, K. (Eds.), Plankton Stratigraphy: Cambridge (Cambridge Univ. Press), 427-554.

Pujos, A., 1987. Late Eocene to Pleistocene medium-sized and small-sized "reticulofenestrids." Abh. Geol. Bundensant. Austria, 39:239-277.

Shipboard Scientific Party, 1987. Site 647. In Srivastava, S. P., Arthur, M. A., Clement, B., et al., Proc. ODP, Init. Repts., 105: College Station, TX (Ocean Drilling Program), 675-905.

Wei, W., and Thierstein, H. R., 1991. Upper Cretaceous and Cenozoic calcareous nannofossils of the Kerguelen Plateau (Southern Indian Ocean) and Prydz Bay (East Antarctica). In Barron, J., Larsen, B. et al., Proc. ODP, Sci. Results, 119: College Station, TX (Ocean Drilling Program).

Wei, W., and Wise, S. W., Jr., 1989. Paleogene calcareous nannofossil magnetobiochronology: results from South Atlantic DSDP Site 516. Mar. Micropaleontol., 14:119-152. 1990a. Middle Eocene through Pleistocene calcareous nannofossils recovered by Ocean Drilling Program Leg 113 in the Weddell Sea. In Barker, P. F., Kennett, J. P., et al., Proc. ODP, Sci. Results, 113: College Station, TX (Ocean Drilling Program), 639-666.

1990b. Middle Eocene-Oligocene calcareous nannoplankton biogeographic gradient of the South Atlantic Ocean. Palaeogeogr., Palaeoclimatol., Palaeoecol., 79:29-61.

Date of initial receipt: 1 September 1989

Date of acceptance: 12 December 1990

Ms 120B-157 

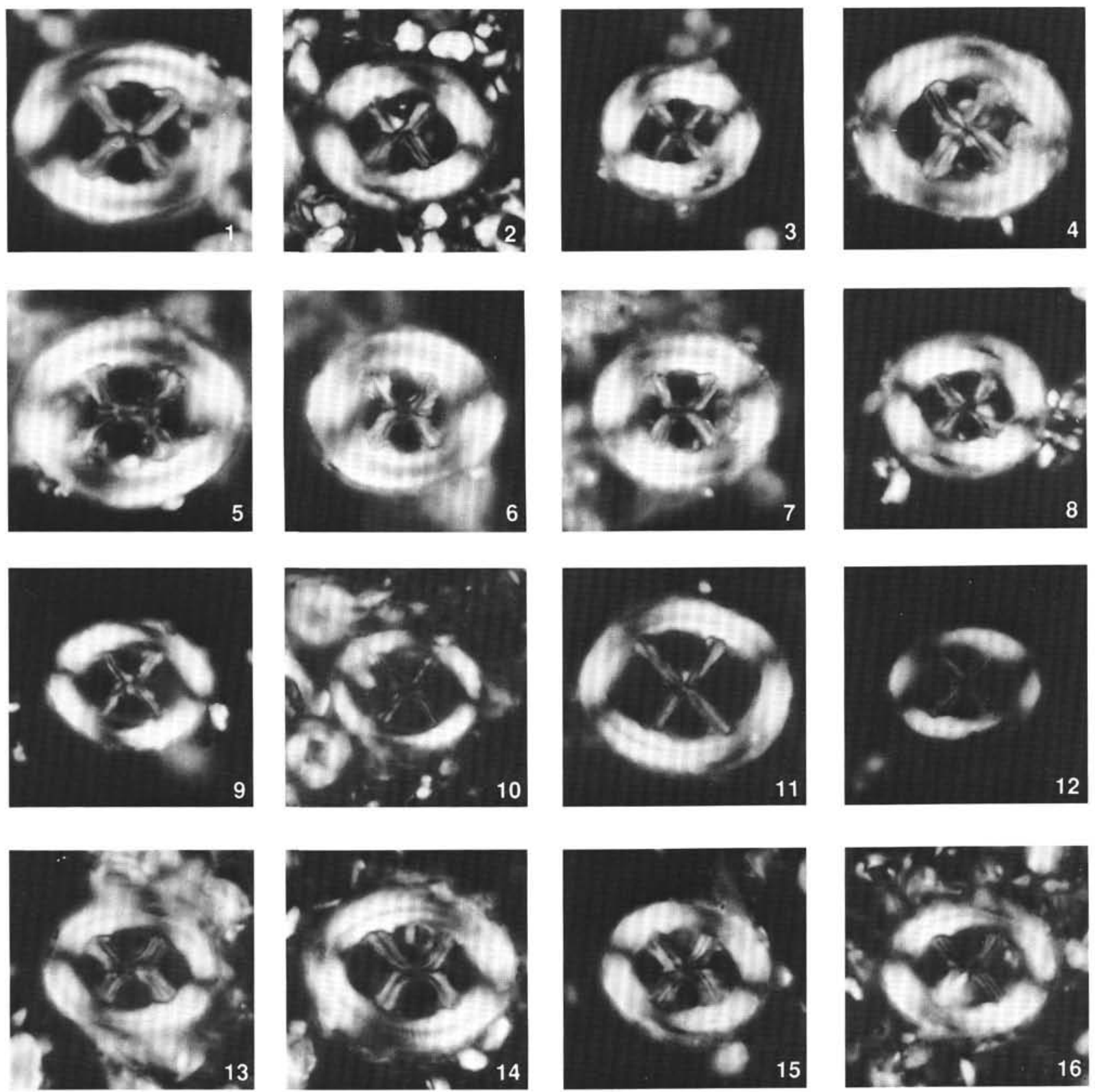

Plate 1. Specimens of Chiasmolithus from the upper middle Eocene. Each sample shows a transition from C. expansus (left) to intermediate or $C$. altus forms (right). 1-4. Sample 120-748B-17H-6, 10-11 cm. 5-8. Sample 120-748B-18H-3, 10-11 cm. 9-12. Sample 105-647A-46R-1, 101-103 cm. 13-16. Sample 105-647A-47R-5, 43-45 cm. 

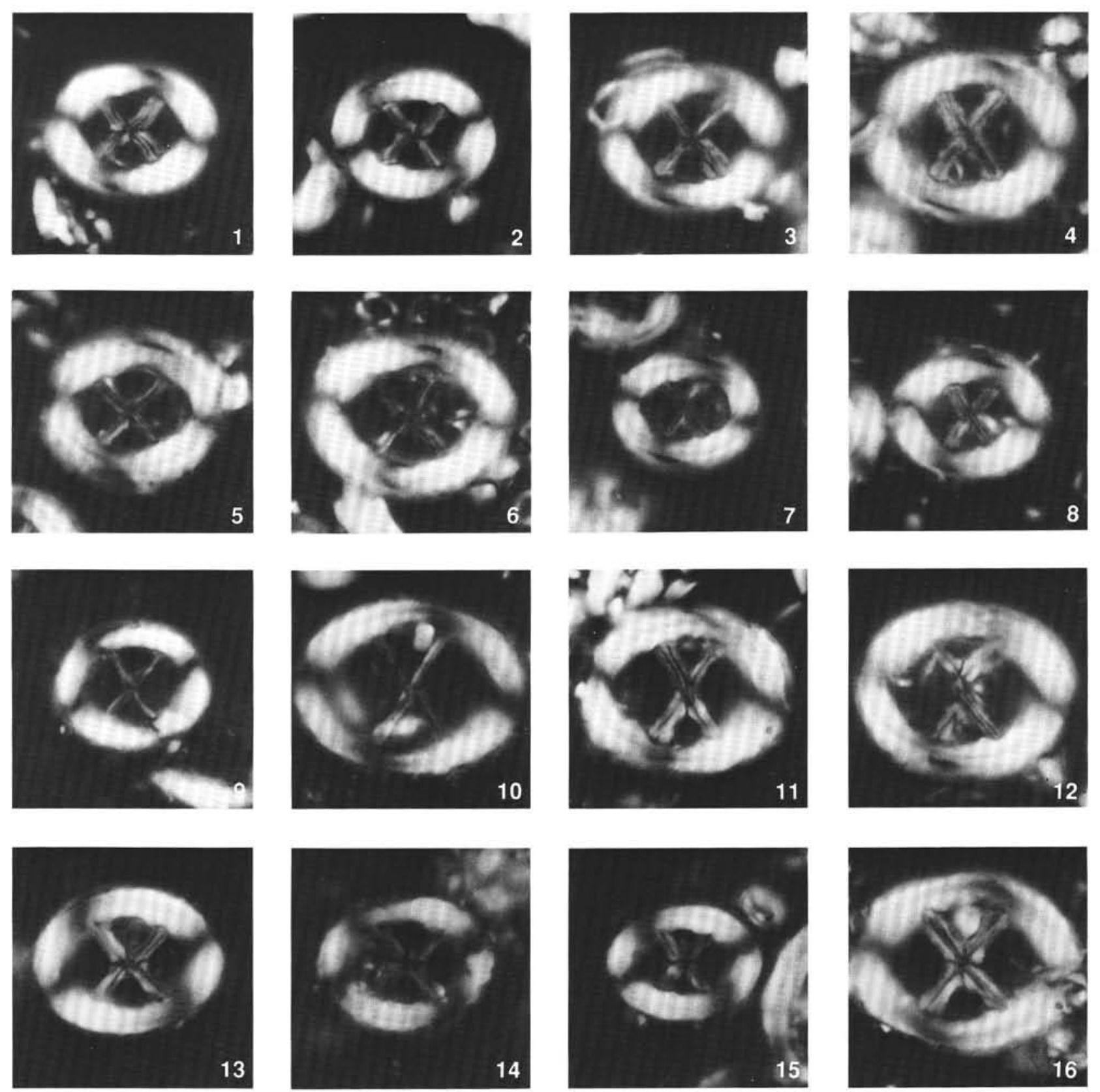

Plate 2. Specimens of Chiasmolithus from the upper Eocene to the middle Oligocene. Each sample indicates a transition from C. altus or intermediate forms (left) to $C$. oamaruensis (right). 1-4. Sample 105-647A-20R-1, 106-108 cm, middle Oligocene. 5-8. Sample 105-647A-28R-3, 71-73 cm, lower Oligocene. 9-12. Sample 105-647A-35R-1, 36-38 cm, upper Eocene. 13-16. Sample 105-647A44R-6, 101-102 cm, upper Eocene. Compare the middle Oligocene specimens of $C$. altus (1-4) with the upper middle Eocene specimens $4,8,12$, and 16 of Plate 1 . 